Diabetologia 3, 249-265 (1967)

\title{
Spontaneous Diabetes in Dogs and Cats*
}

\author{
A Pathological Study
}

\author{
W. GePts and D. ToussatnT
}

\begin{abstract}
Department of Pathology and Department of Ophtalmology, Brugmann University Hospital and Fondation Médicale Reine Elisabeth, Brussels - Belgium
\end{abstract}

Summary. A histological study of 30 spontaneously diabetic dogs and 5 spontaneously diabetic cats is presented. - The islets of Langerhans and the B cells were strongly reduced in number in a large majority of the diabetic dogs. The $\mathrm{B}$ cells were often degranulated and hydropic. In cases of longer duration, the islets were scarce and $B$ cells could no longer be found. - In contrast to the findings in diabetic dogs, all five cats showed numerous islets and B cells. However in 4 cats, the B cells showed complete degranulation and hydropic changes, as in the dogs. In one cat, the B cells had a normal appearance. Extensive hyalin deposits were found in the stroma of the islets in 2 cats. In one cat, an islet showed a dense lymphocytic infiltration. - No lesions identical to human diabetic glomerulosclerosis were found in any of the dogs or cats. The changes most frequently observed were a variable degree of thickening of the mesangial stalk of the glomerular capillaries, and an hypertrophy of the wall of the afferent arteriole. Scars resulting from chronic pyelonephritis, were found in a few dogs and cats. Acellular, non-functional capillaries, with degeneration of pericytes ("ghost-cells") were found in larger numbers in the retinas of the diabetic dogs than in non-diabetic control dogs. A very few microaneurysms could be found in 3 dogs. The lower incidence of the most typical lesions of diabetic retinopathy in dogs, as compared with the human diabetic, is probably related to the shorter duration of the disease in these animals. However, a lower susceptibility of the retina of dogs and cats to develop degenerative changes cannot be excluded. A severe steatosis was observed in the liver of many dogs and cats. In 4 dogs, the liver showed early cirrhosis. In diabetic dogs and cats, the adrenal cortex often showed hypertrophy and contained adenomas; however, these changes have also been reported in non-diabetic aging dogs. An adenoma was found in 2 of the 7 pituitaries obtained from diabetic dogs; the cytological aspect of these adenomas and of the pituitaries will be reported in a later publication.

Diabète spontané chez les chiens et les chats. Etude histopathologique.

Résumé. Les auteurs présentent une étude histopathologique de 30 chiens et de 5 chats spontanément diabétiques. - Les îlots de Langerhans et les cellules $\mathrm{B}$ étaient fortement diminués en nombre chez la grande majorité des chiens. Les cellules $B$ étaient souvent dégranulées et hydropiques. Chez les chiens dont le diabète avait évolué pendant longtemps, les îlots étaient très rares et les cellules $B$ absentes. - Chez les 5 chats spontanément diabétiques par contre, les îlots et les cellules B étaient nombreuses. Les cellules B étaient dégranulées et hydropiques chez 4 chats. Chez 1 des chats, les cellules $B$ paraissaient normales. De nombreux îlots présentaient des dépôts de substance hyaline dans le stroma. Chez un chat, il existait une infiltration lym-

* Supported by the Belgian Fonds de la Recherche Scientifique Médicale (Grant $n^{\circ} 711$ ) and U.S. National Institute of Metabolic and Arthritic Diseases (N.I.H. Research grant AM-06490-03 PTHA). phocytaire très dense dans un îlot. - Ni chez les chiens, ni chez les chats, il n'a été vu de lésions glomérulaires identiques à celles de glomérulosclérose diabétique humaine. Les lésions les plus fréquentes consistaient en un épaississement des axes membraneux des touffes glomérulaires et une hypertrophie de la paroi des artérioles afférentes. Dans les rétines des chiens diabétiques il existait une acellularité focale ou généralisée de la paroi des capillaires. Un petit nombre de microanévrysmes ont été trouvés chez 3 chiens diabétiques. L'incidence plus faible des lésions de rétinopathie vaseulaire, comparativement aux diabétiques humains, s'explique probablement par la durée de vie plus courte du chien et du chat. Il est possible aussi que les capillaires rétinions de ces animaux soient moins susceptibles de développer des lésions dégénératives. - Un degré marqué de stéatose hépatique a été observé chez beaucoup de chiens et de chats. Les surrénales étaient souvent hypertrophiées et contenaient des adénomes, mais ces lésions ne paraissent pas différentes de celles que l'on peut trouver chez des chiens et des chats non diabétiques de même âge. L'hypophyse a été prélevée chez 7 chiens. Dans 2 cas, elle contenait un adénome. Une étude cytologique plus complète des hypophyses sera publiée ultérieurement.

Spontandiabetes bei Hunden und Katzen. Eine pathologisch-anatomische Untersuchung.

Zusammenfassung. Die Autoren berichten über die Ergebnisse von Untersuchungen an 30 spontan-diabetischen Hunden und 5 spontan-diabetischen Katzen. Bei der großen Mehrzahl der diabetischen Hunde war die Zahl der Langerhansschen Inseln und der B-Zellen stark herabgesetzt. Die B-Zellen waren oft degranuliert und hydropisch. Bei Hunden mit schon lang anhaltender Krankheit waren die Inseln nur noch vereinzelt und B-Zellen überhaupt nicht mehr nachweisbar. - Im Gegensatz zu diesen Ergebnissen fanden sich bei allen 5 Katzen zahlreiche Inseln und B-Zellen. Bei 4 dieser Katzen jedoch waren die B-Zellen, wie bei den Hunden, degranuliert und hydropisch entartet. Bei einer Katze war das Aussehen der B-Zellen normal. Im Stroma der Inseln von 2 Katzen konnten starke Hyalinablagerungen nachgewiesen werden. In einem Falle zeigten die Inseln eine starke lymphocytäre Infiltration. - Weder boi den Hunden noch bei den Katzen waren typische Läsionen der Glomeruli, wie sie bei der Glomerulosklerose des menschlichen Diabetes auftreten, nachweisbar. Die häufigsten Veränderungen bestanden aus einer mehr oder weniger ausgeprägten Verdickung des mesangialen Teils der Kapillaren der Glomeruli und aus einer Hypertrophie der Wand der zuführenden Arteriolen. Bei einigen Hunden und Katzen bestanden auf chronische Pyelonephritis zurückführende Narben. - In der Retina der diabetischen Hunde waren zellenlose und funktionslose Kapillaren vorhanden, und degenerierte Pericyten ("ghostcells") waren häufiger als bei normalen Hunden. In drei Hunden wurden einige Mikroaneurismen beobachtet. Daß diese für die Retinopathie des Diabetes typischen Läsionen beim Hund verhältnismäßig selten auftreten könnte mit der kürzeren Lebensdauer der Krankheit bei diesen Tieren zusammenhängen. Es ist jedoch nicht ausgeschlos- 
sen, daß die Retina von Hunden und Katzen weniger zu degenerativen Veränderungen neigt. - In der Leber vieler Hunde und Katzen wurde eine schwere Steatose beobachtet. In vier Hunden zeigte sich beginnende Lebercirrhose. In diabetischen Hunden und Katzen waren die Nebennieren oft hypertrophisch und enthielten Adenome, die allerdings auch bei nichtdiabetischen alternden Hunden beobachtet wurden. In 2 von 7 Hypophysen diabe- tischer Hunde fanden sich Adenome, über deren cytologische Untersuchung in einer späteren Veröffentlichung berichtet wird.

Key-words: Spontaneous Diabetes, Dog, Cat, Diabetes in dogs and cats, Pancreas, Islets of Langerhans, B cells, Insulitis, Hyalin, Capillaries, Kidney, Retina, Microaneurysms, Pituitary.
Spontaneous Diabetes mellitus has been reported repeatedly in dogs and cats. Its incidence is not known exactly, but it is estimated by MeIER [26] at $1 / 200$ in dogs and $1 / 800$ in cats. Several excellent studies and reviews have been published on spontaneous canine diabetes $[26,14,35,32,4,42,8,40,41,5,17,11,28$,

\section{Material andMethods}

Thirty dogs and five cats have been studied. The clinical data, when available, have been listed in Tables 1 and 2. No special racial predisposition emerges from our material. The age of the dogs varied from 2 to 13 years; in cats from 7 to 11 years. There is a

Table 1. Clinical data on spontaneously diabetic dogs

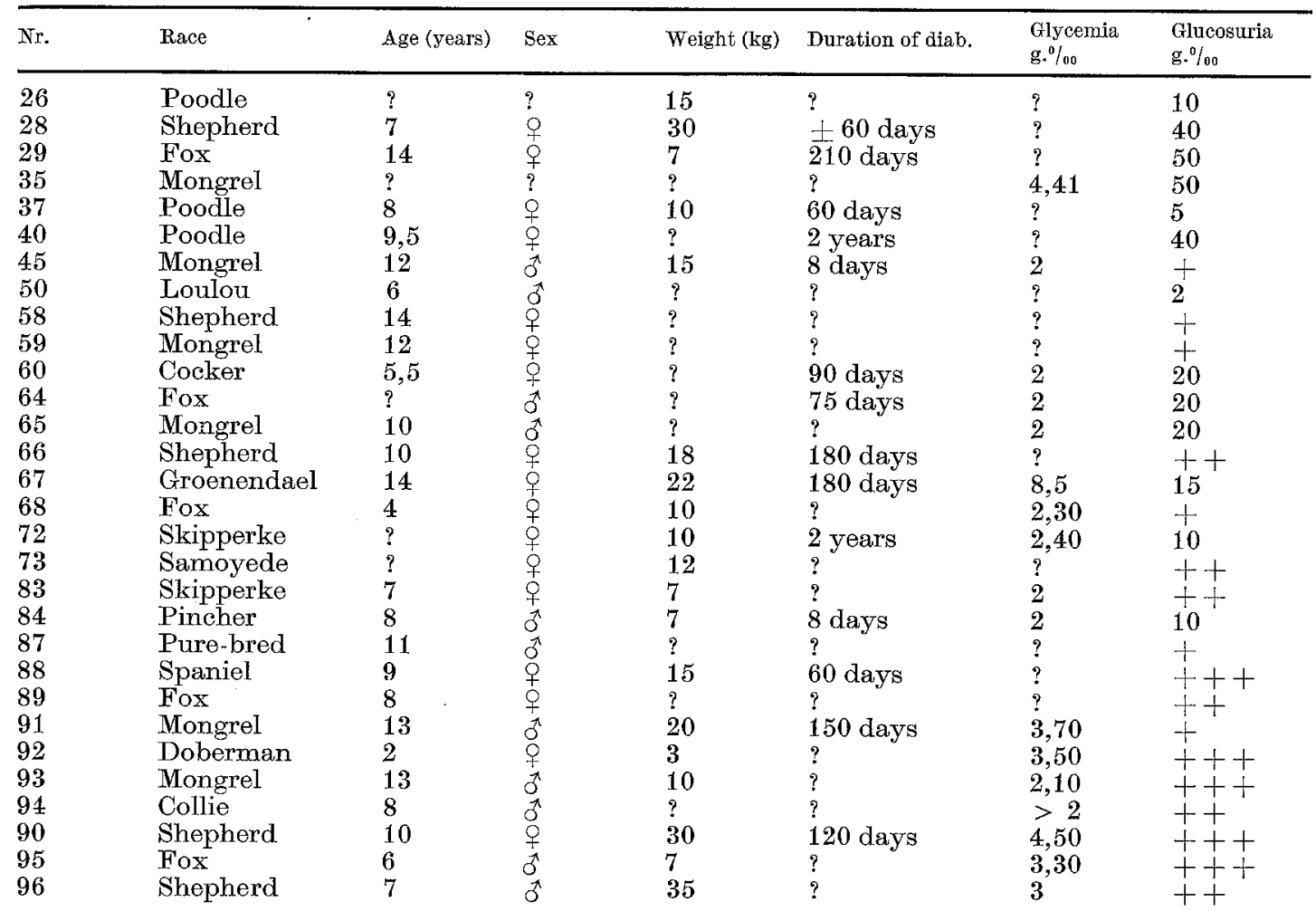

$36,9]$. On spontaneously diabetic cats the information is scarce and mostly confined to single case reports $[35,34,33,25,15,18]$.

For many years we have been collecting material from spontaneously diabetic dogs and cats. The largest part of it was obtained through private veterinarians, who had performed the autopsy after killing the animal at the owner's request. For this reason detailed biochemical data are not available on these cases. Our study is aimed principally at the morphological changes that have been found in the pancreas, the kidneys, the retinas and in other organs of these dogs and cats.
Table 2. Clinical data on spontaneously diabetic cats

\begin{tabular}{lrllll}
\hline Nr. & Age & Sex & $\begin{array}{l}\text { Duration } \\
\text { of diab. }\end{array}$ & $\begin{array}{l}\text { Glycemia } \\
\text { g/l }\end{array}$ & $\begin{array}{l}\text { Glycosuria } \\
\text { g/l }\end{array}$ \\
\hline 36 & 7 & q & $?$ & 2 & ++ \\
47 & 11 & o & 1 month & 2 & ++ \\
51 & 10 & 0 & $?$ & $?$ & ++ \\
62 & 7 & o & 2 months & $?$ & ++ \\
70 & 8 & o & 7 months & + & +++
\end{tabular}

slight preponderance of females in both dogs and cats. We have no data on an eventual diabetic heredity except for dog 28 , on which we have been informed 


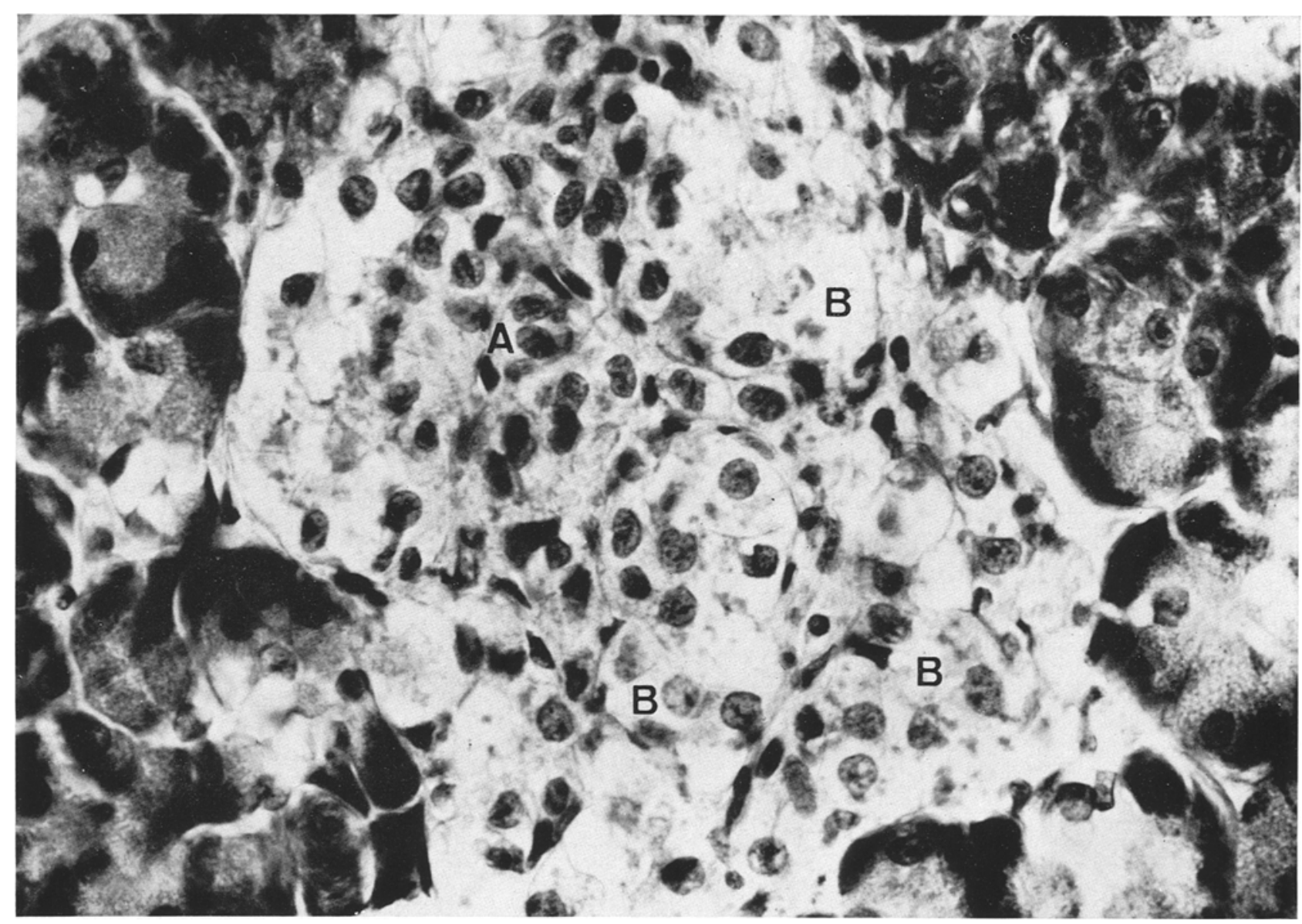

Fig. 1. Diabetic Dog (No. 50). Islet of Langerhans. Swelling and hydropic change of the B cells. Hemalum-erytrosine-saffron. A:A cells - B: B cells. $800 \times$

that the mother and a female litter-mate were also diabetic.

The duration of the diabetes was estimated from the symptoms related by the owners of the animals. In dogs it ranged from a few days to 3 years, in cats from 1 to 7 months. The diagnosis of diabetes was based on clinical symptoms (polydipsia, polyuria, weight loss), glycosuria and/or hyperglycemia.

Slices of pancreas, kidney, liver, the adrenals and in some of the cases the pituitary were fixed in Romeis' or in Bouin's fluid. Paraffin sections were stained by hemalum-erythrosine-saffron, Gomori's chromium hematoxylin-phloxine method, aldehyde-fuchsin trichrome [20], Ivic's Victoria Blue method [16], Manocchio's toluidine blue reaction for metachromatic cells [23], and Dominici's toluidine blue-erythrosine-orange [24].

One of the eyeballs was fixed either in Romeis' or in Bouin's fluid. An equatorial segment comprising the optic nerve was embedded in paraffin, cut at $5 \mu$, and stained with hematoxylin-eosin and the periodic acid Schiff reagent (PAS). The remaining part of this retina was flat mounted and embedded in paraffin, cut at $5 \mu$ and stained with the same methods. The other eyeball was fixed in $10 \%$ formalin; after fixation the retina was dissected and incubated with a $1 \%$ trypsin solution for 2 hours. The isolated retinal vasculature was mounted on a glass slide and stained with PAS, toluidine blue, and the May-Grunwald method. The retinas from 7 non-diabetic dogs and 4 non-diabetic eats were used as controls.

\section{Histologic findings}

\section{Pancreas (Table 3)}

A. Dogs The chief histological findings in the islet tissue are summarized in Table 3 . In 18 dogs the islets were markedly reduced in number. In 5 of these 18 cases, a careful study of numerous slides failed to discover one single islet. In the remaining 13 cases a few islets were found, most of them small in size. In 2 of these cases they contained only small cells that sometimes stained with phloxin, as A cells, but often did not show any particular staining affinity. In the remaining 11 cases $B$ cells were still present; they were completely degranulated, swollen and vacuolated (Fig. 1) in 8 cases; in 3 other cases, they showed degranulation but no hydropic change.

In 7 dogs the islets were still numerous. However, in 2 of them, they were small and composed of small undifferentiated cells. In 2 dogs with fairly numerous 


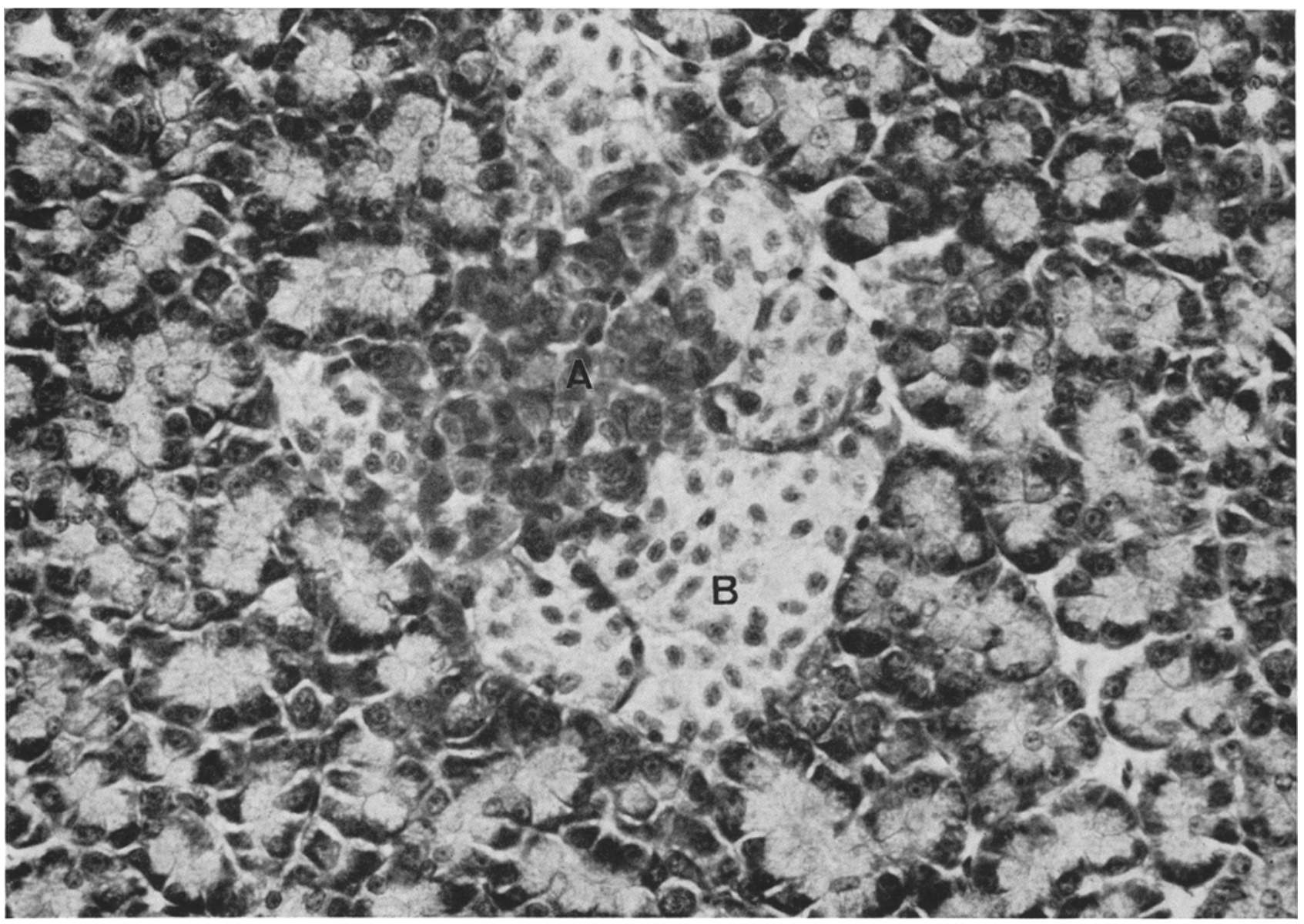

Fig. 2. Diabetic Dog (No. 35). Islet of Langerhans. The B cells are numerous and degranulated. A: A cells - B: B cells. Chromium hematoxylin-phloxine. $400 \times$

Table 3. Histological changes in the islet tissue of spontaneously diabetic dogs

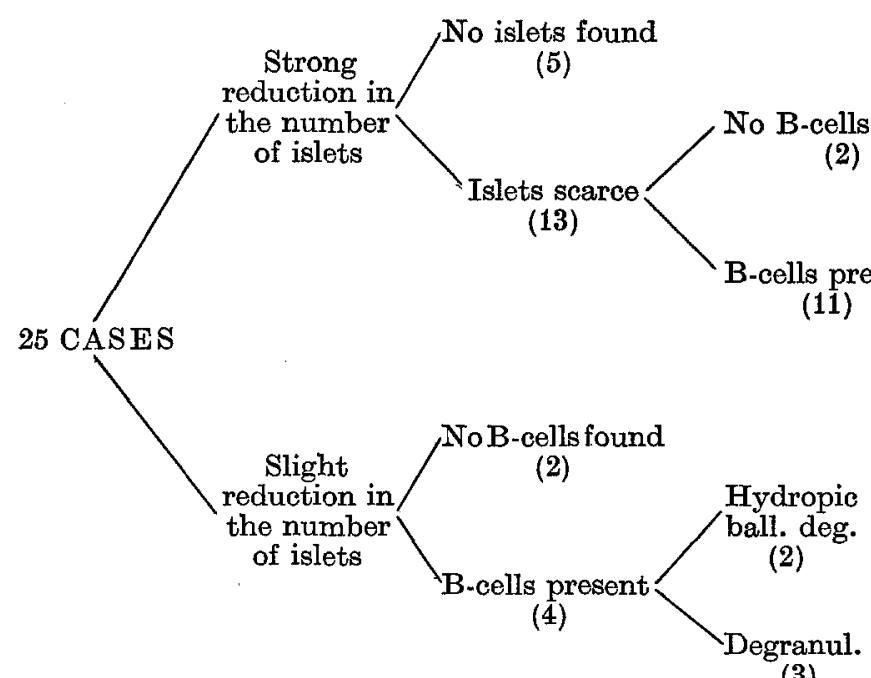

(3)

islets, the B cells were completely degranulated, swollen and vacuolated. In the remaining 2 dogs of this group, the $\mathrm{B}$ cells showed only a varying degree of degranulation (Fig. 2).
With the PAS method variable amounts of glycogen could be demonstrated. Many of these cells had a ballooned appearance and showed nuclear pycnosis. In other B cells, especially in those with a less extreme 


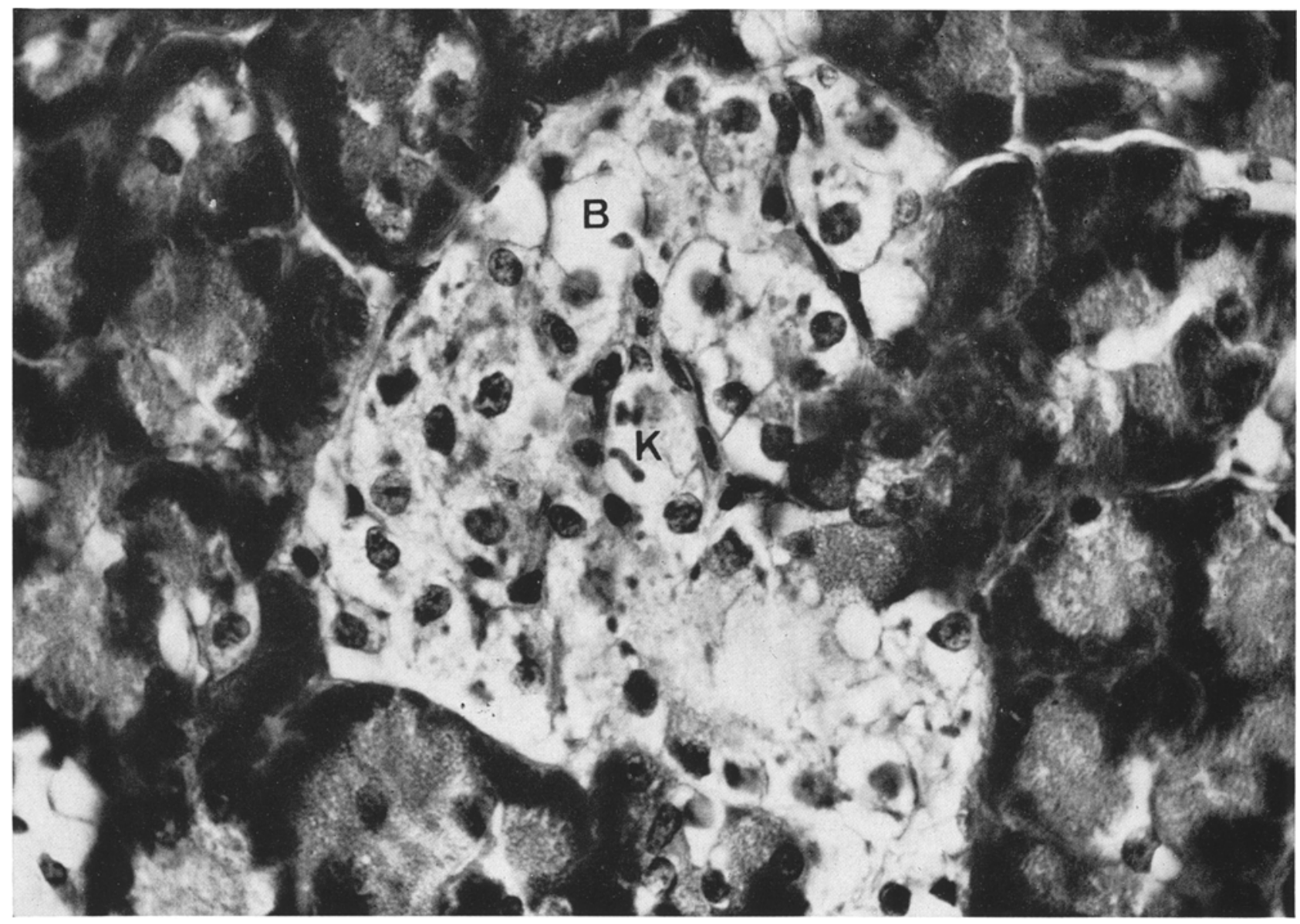

Fig. 3. Diabetic Dog (No. 50). Islet of Langerhans. Hydropic change of the B cells. B: B cells - K: “Körnchen”. Toluidine Blue. $800 \times$

degree of hydropic change, the cytoplasm contained irregular small particles (Fig. 3), which were particularly well brought out with toluidine blue. A previous incubation of the section with $0.1 \%$ ribonuclease abolished this staining affinity. It appears therefore, that these particles represent $\mathrm{RNA}$, present in increased amounts in the cytoplasm of these B cells.

The quantitative changes in the A cells, D cells and in the metachromatic cells roughly paralleled those of the islets and of the B cells. In the few cases in which the $B$ cells were relatively numerous, typical A cells, D cells and metachromatic cells were easy to find; they showed no abnormality whatsoever. In the other cases, with few islets and few or no $B$ cells, these cells were also strongly reduced in number or could not be found at all.

Vacuolisation of the epithelium of the inter- and intralobular ducts was the most prominent change in the exocrine part of the pancreas. Focal acute pancreatitis was observed in 4 dogs and a diffuse acute pancreatitis in one dog. Focal chronic pancreatitis and pancreatic fibrosis of the perilobular type were present in a small number of dogs.

Table 4. Histological changes in the islet tissue of spontaneously diabetic cats

5 cases

Number of islets $=$ Normal in all cases B-cells numerous in all cases

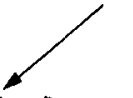

Hydropic change Ballooning degener.

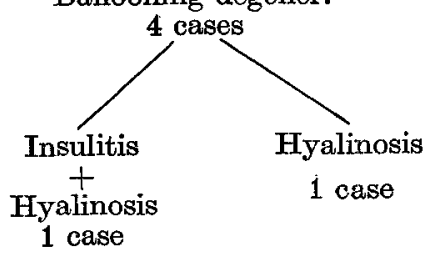

B. Cats (Table 4). In all 5 cats the islets were numerous and often large. Quantitative measurements have not been performed, but the amount of islet tissue in the pancreas of our cats often suggested some degree of hyperplasia.

In 4 cats, the islets were composed mainly of degranulated, swollen, and hydropic B cells (Fig. 4). In many islet cells the vacuolisation had attained an 


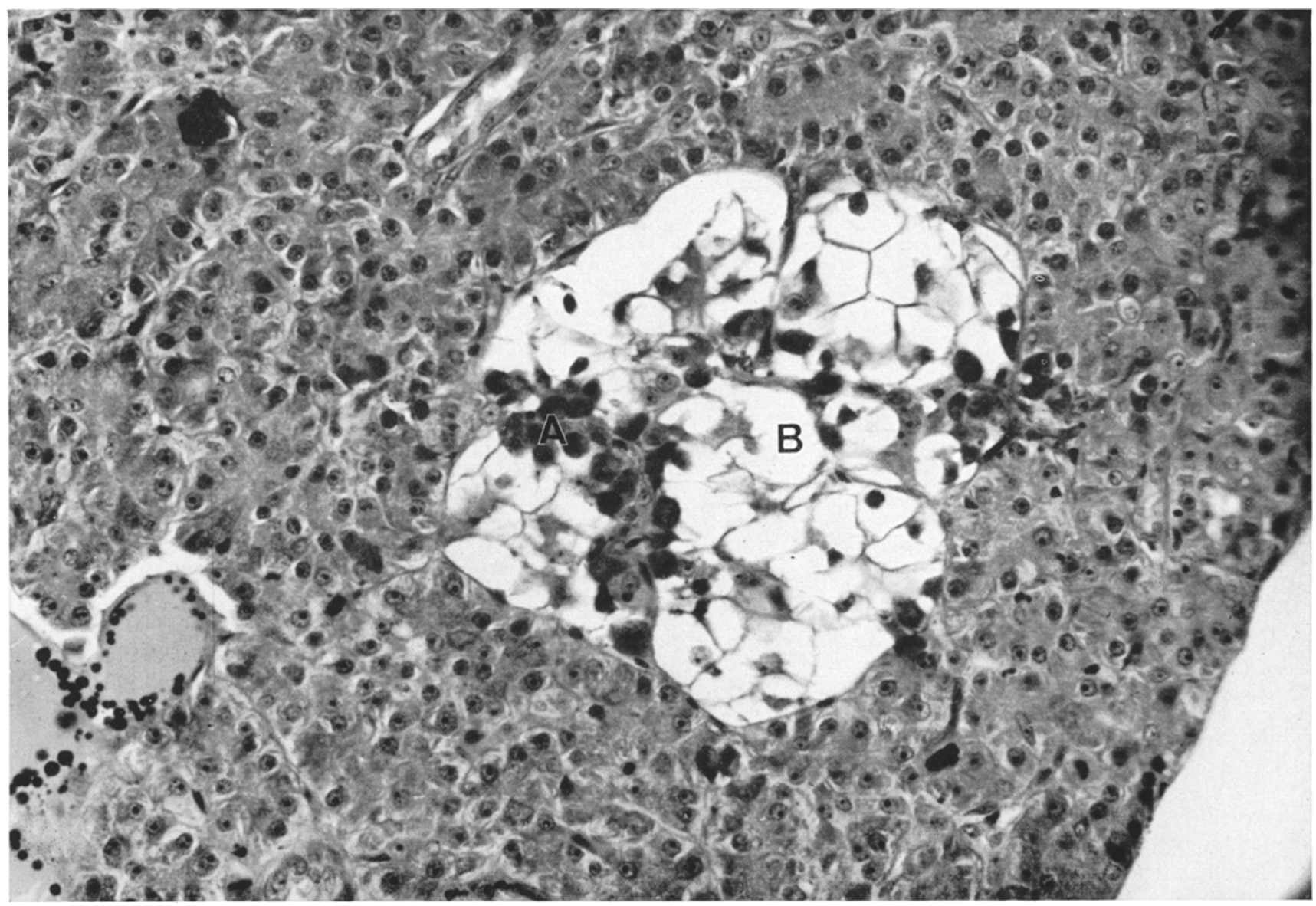

Fig. 4. Diabetic Cat (No. 47). Islet of Langerhans. Hydropic B cells. A: A cells - B:B cells. Hemalum-ery trosine-saffron. $400 \times$

Table 5. Histological changes in the kidneys of spontaneously diabetic dogs and cats

\begin{tabular}{|c|c|c|c|c|c|c|c|}
\hline & \multirow[t]{2}{*}{$\begin{array}{l}\text { Normal } \\
\text { glomer. }\end{array}$} & \multicolumn{3}{|c|}{$\begin{array}{l}\text { Thickening of glomer. } \\
\text { basement membr. } \\
\text { mesangial }\end{array}$} & \multirow[t]{2}{*}{ diffuse } & \multirow[t]{2}{*}{ Pyelonephritis } & \multirow[t]{2}{*}{$\begin{array}{l}\text { Giycogen } \\
\text { in tub. epith. }\end{array}$} \\
\hline & & + & ++ & +++ & & & \\
\hline $\begin{array}{l}\text { Dogs } \\
23 \text { cases }\end{array}$ & 10 & 9 & 5 & 2 & 2 & 2 & 7 \\
\hline $\begin{array}{l}\text { Cats } \\
5 \text { cases }\end{array}$ & 5 & 0 & 0 & 0 & 0 & 2 & 3 \\
\hline
\end{tabular}

extreme degree and was associated with nuclear pycnosis, recalling the ballooning degeneration as described by LAzarus and VoLK [20]. Small amounts of glycogen could be demonstrated in these vacuolated islets cells. In the central area of the islet cells a small core of A cells was often present.

In 2 cats abundant deposits of a hyaline substance were present in numerous islets (Fig. 5). This hyaline substance had the tinctorial characteristics of amyloid. In several islets it replaced almost completely the islet cells; in others, it surrounded remnants of more or less degenerated, hydropic B cells.

In one of the cats with hyaline changes, a dense inflammatory infiltrate consisting of small lympho- cytes was discovered in one islet (Fig. 6). No other example of this lesion could be found either in numerous sections from the same pancreas, or in the other diabetic cats. In the islet showing inflammatory infiltration, the $\mathbf{B}$ cells were hydropic.

In 1 cat, the islets were not only numerous but contained well granulated A and B cells. As a matter of fact no abnormality whatsoever could be demonstrated in the islet tissue of this animal.

Kidneys (Table 5) Dogs. The lesions in the kidneys of the diabetic dogs were very irregular. Many dogs with a diabstes of fairly long duration showed no or only minor changes. Often these did not differ from those that have been described in the kidneys of 


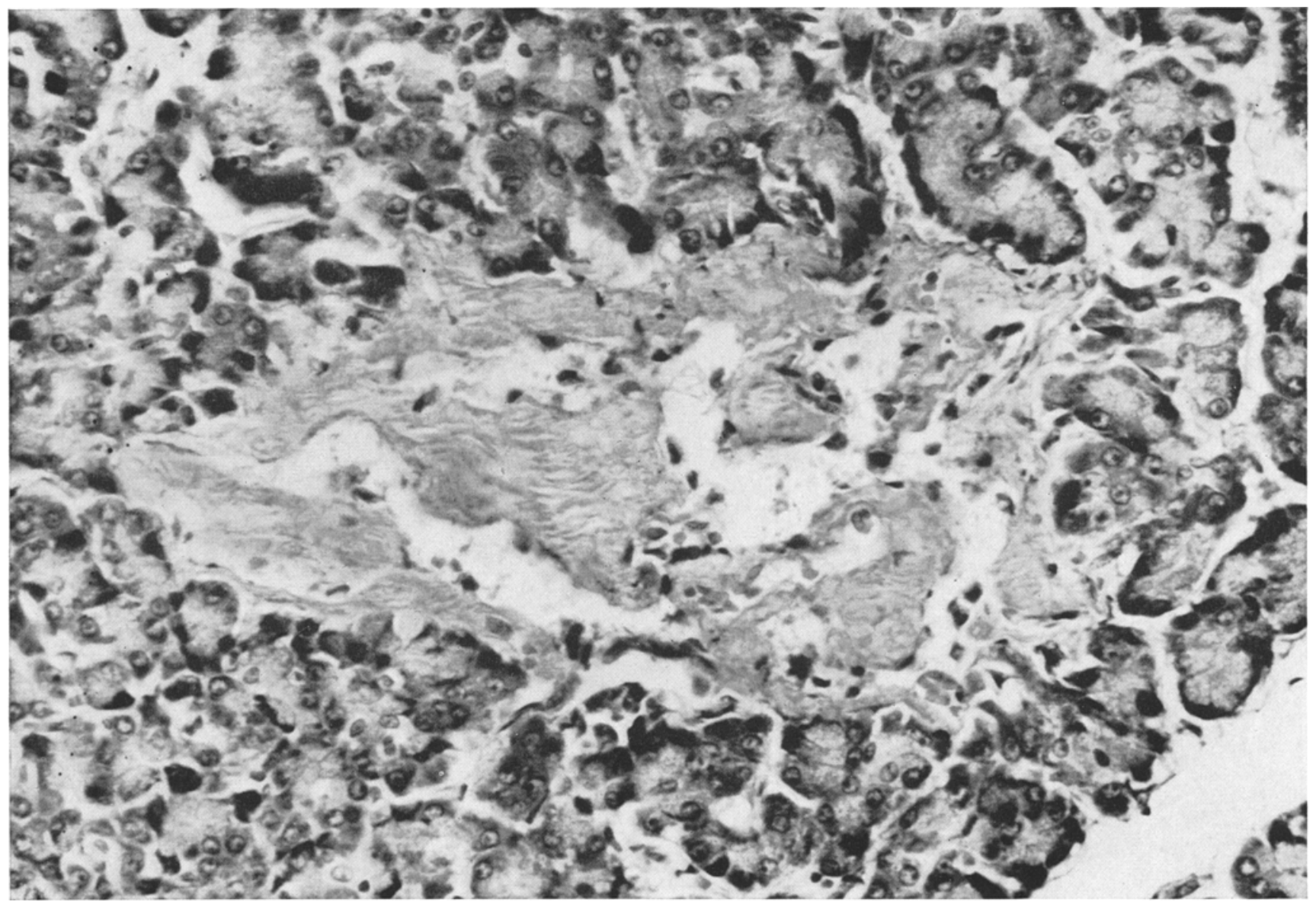

Fig. 5. Diabetic Cat (No. 70). Islet of Langerhans. Severe hyalinosis. Chromium hematoxylin-phloxine. $400 \times$

aging non-diabetic dogs. The most frequent change consisted in a mesangial thickening resulting from the deposition of a PAS-positive substance (Fig. 7). This mesangial thickening often appeared continuous with a thickening of the wall of the afferent arteriole. Only rarely did it extend in the peripheral part of the glomerular capillaries, evoking the diffuse type of human diabetic glomerulosclerosis (Fig. 8). Lesions resembling, but not identical to the nodular type of human diabetic glomerulosclerosis, were found in a very few glomeruli in 2 dogs (Fig. 9). In one dog, the glomerular capillaries had a wide lumen (Fig. 10), as if distended by some material that had been dissolved out from the sections during the embedding process. Unfortunately, wet tissue no longer being available, staining for fat could not be performed.

Foci of interstitial nephritis, probably of pyelonephritic origin, were found in 2 dogs. Hydropic change due to glycogen deposition (Armani-Ebstein change) was observed in the ascending limbs of Henle's loop in 7 dogs. Except for the thickening of the wall of the afferent arterioles, already mentioned together with the glomerular lesions, no vascular lesions were found.

Cats. Only minor changes were found in the kidneys of the diabetic cats. Pyelonephritic scars were present
Table 6. Retinal vascular changes in spontaneously diabetic dogs and cats

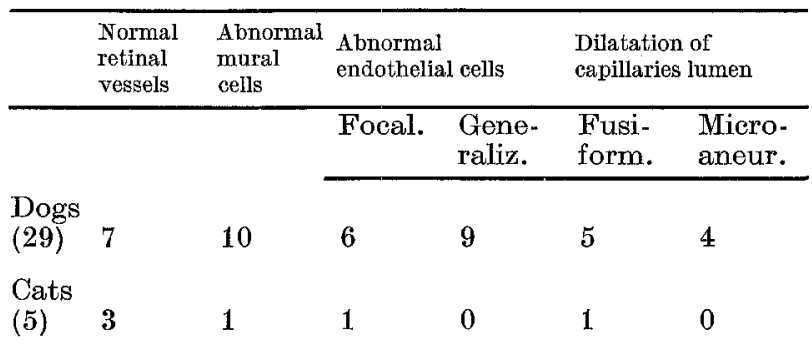

in 2 cats. Hydropic change in the epithelium of the ascending loop of Henle was recorded in 3 cats.

Retinas (Table 6)

Before reporting on the changes in the retinas of our diabetic dogs and cats it may be worth while to describe briefly the characteristics of the retinal capillaries in these species. Their wall contains two types of cells: endothelial cells and pericytes (Fig. 11). The endothelial cells have an elongated nucleus. The pericytes ("mural cells" of Kuwabara and Cogan) have a more spherical nucleus; they often protrude on the outer side of the capillary wall. In the cat (Fig. 14), the nuclei of the pericytes may appear spherical, 


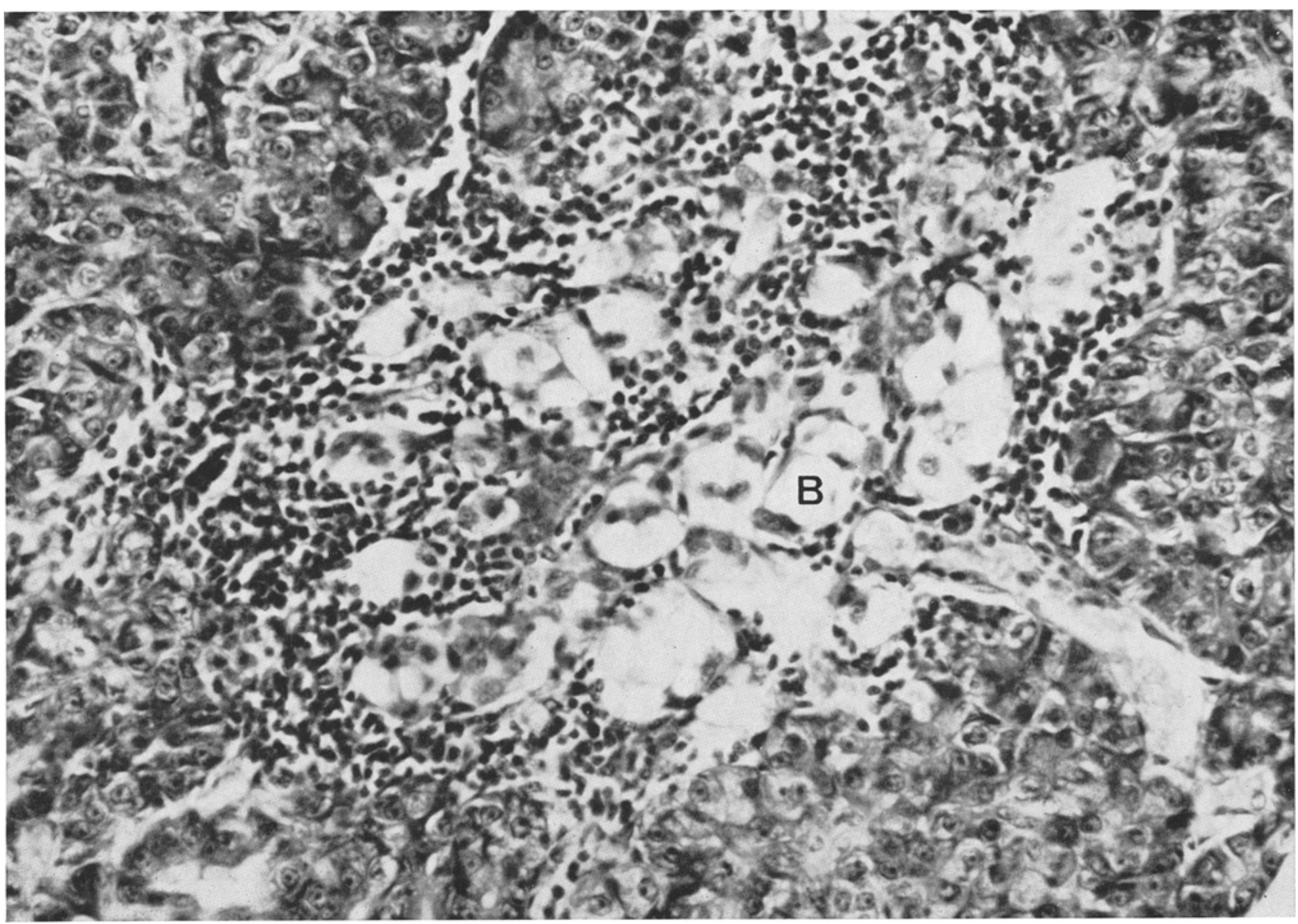

Fig. 6. Diabetic Cat (No. 47). Dense lymphocytic infiltration in an islet of Langerhans with hydropic B cells. Hemalum-erytrosine-saffron. 400 $\times$

but their darker staining and their location within the basement membrane are helpful in their recognition. The pericytes in the retinal capillaries of normal dogs and cats appear less numerous than in the retina of the human.

Most of the abnormalities that we shall describe, were discovered in retinas studied with the trypsin digestion method. Very few lesions could be detected in flat-mounted, whole retinas. The following changes have been recorded:

1. Typical microaneurysms (Fig. 13) located in the posterior part of the retina in 4 dogs. We want to stress the fact that in each of these dogs only very few microaneurysms could be discovered. No microaneurysms were found in the diabetic cats. Neither have they been found in non-diabetic dogs and cats.

2. Degeneration of the pericytes presenting as mural ghost cells (Fig. 12) was observed in 10 dogs and in 1 cat. It has not been observed in the non-diabetic dogs or cats.

3. Acellularity of the capillary walls (Fig. 15), resulting from loss of pericytes and endothelial cells, was seen focally in 6 dogs and 1 cat. Generalized acellularity of the retinal capillaries was observed in
9 dogs; it was not seen in the cats. Non-functional, acellular capillaries can be found, but in smaller number, in non-diabetic dogs and cats.

4. Irregularities in the width of retinal capillaries, without true aneurysms, were seen in 5 dogs and 1 cat. They have not been found in non-diabetic dogs or cats.

Liver

The major abnormality observed in the liver was fatty change of the parenchymal liver cells. It was present in 14 dogs and in 2 cats. It was severe in 6 dogs, moderate in 5 and slight in 3 . In cats it was moderate. In 4 dogs with steatosis, the liver also showed early cirrhosis. Marked centro-lobular congestion, probably related to a terminal circulatory collapse, was present in nearly all the dogs and cats.

Adrenals

The adrenals were available in $20 \mathrm{dogs}$ and in 3 cats. Cortical hypertrophy with adenomatous nodules, was found in 14 dogs and in all 3 cats. The adenomas were composed of large spongiocytes. In some of them foci of necrosis and calcification were present.

Pituitary

The pituitary was available in 7 of the diabetic dogs. A small adenoma was discovered in 2 of these 


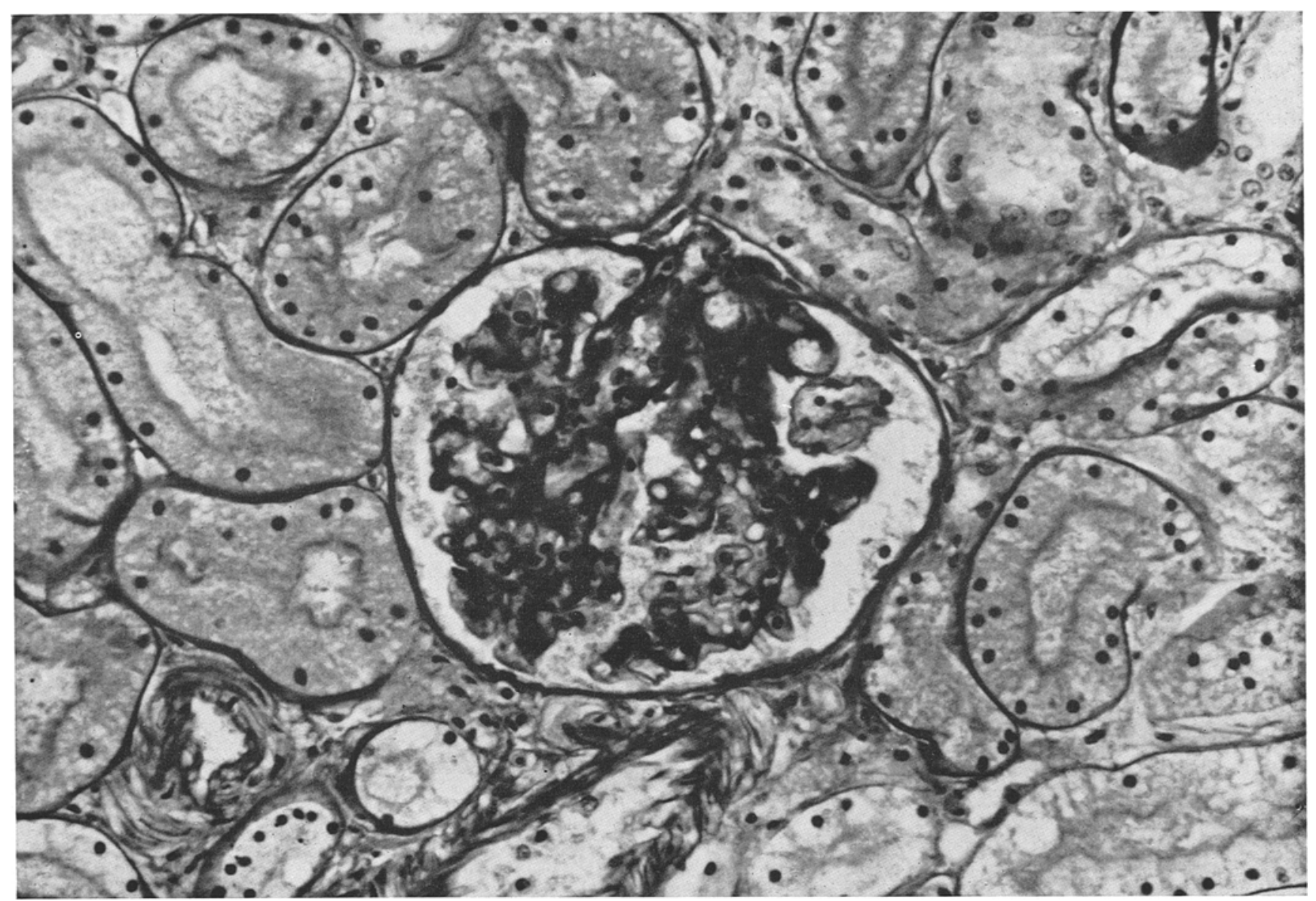

Fig. 7. Diabetic Cat (No. 70). Kidney. Moderate thickening of the mesangial stalk. PAS $400 \times$

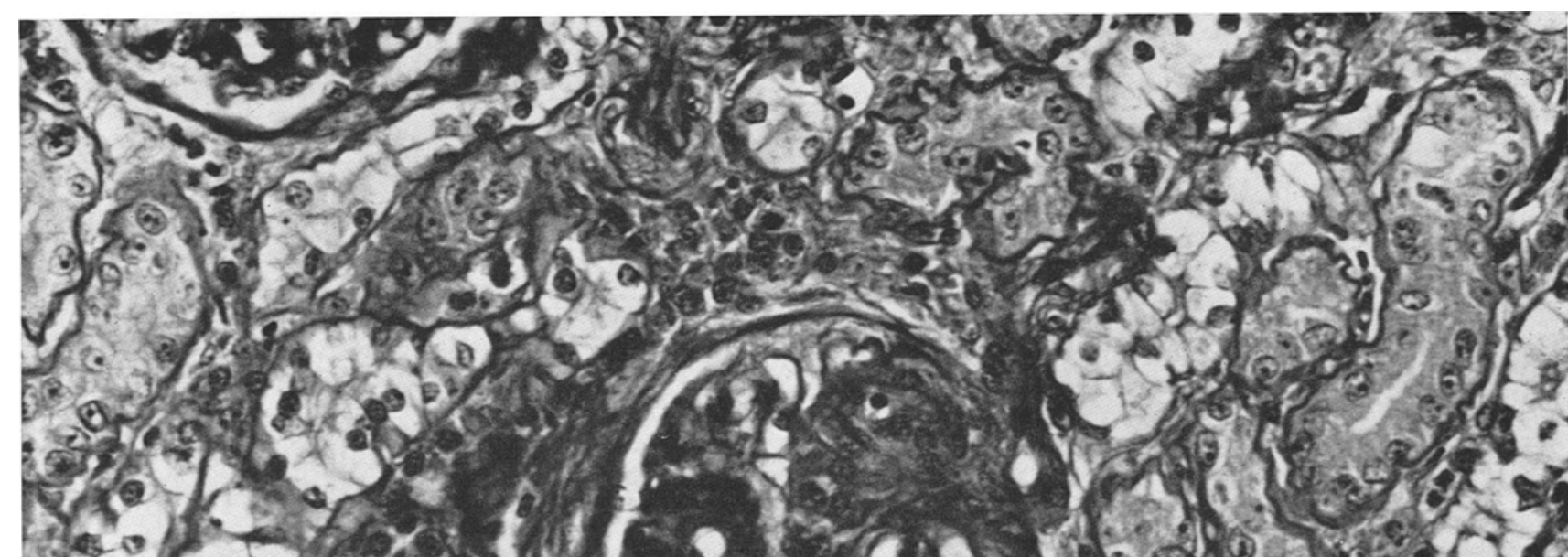

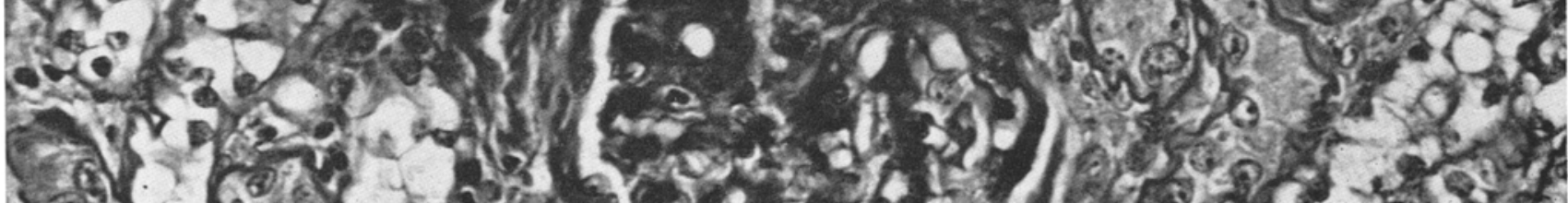

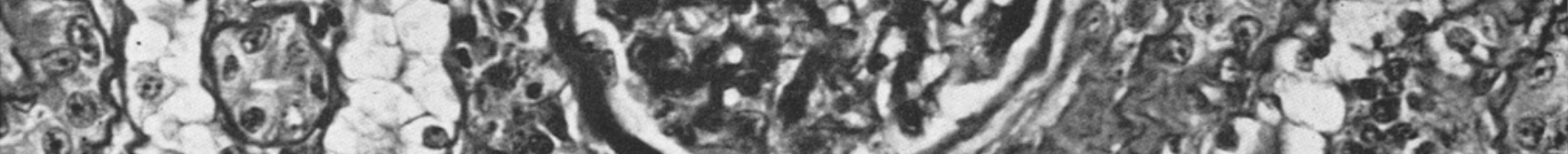

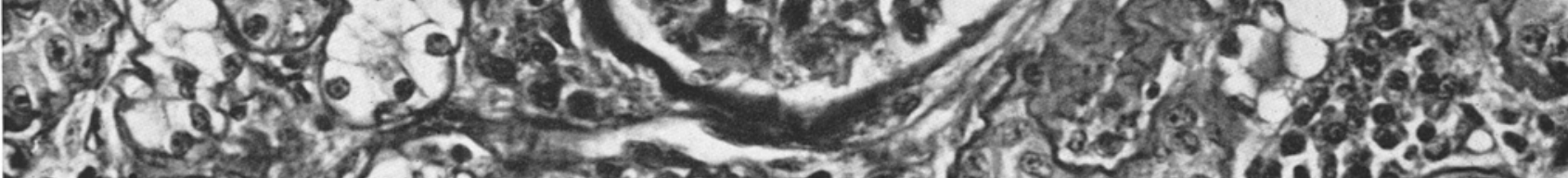

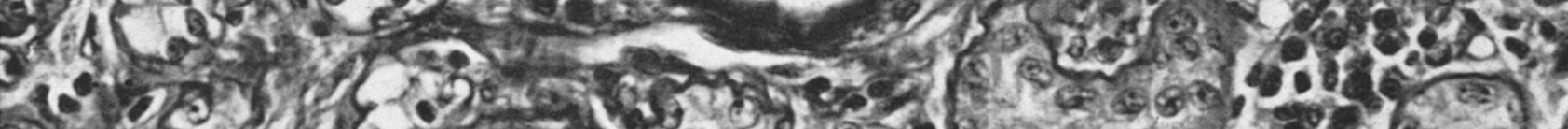

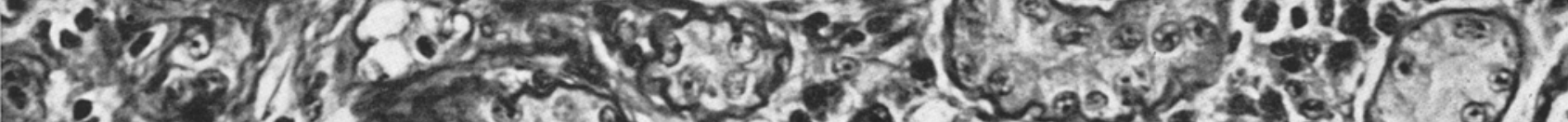
3.0
Ens 


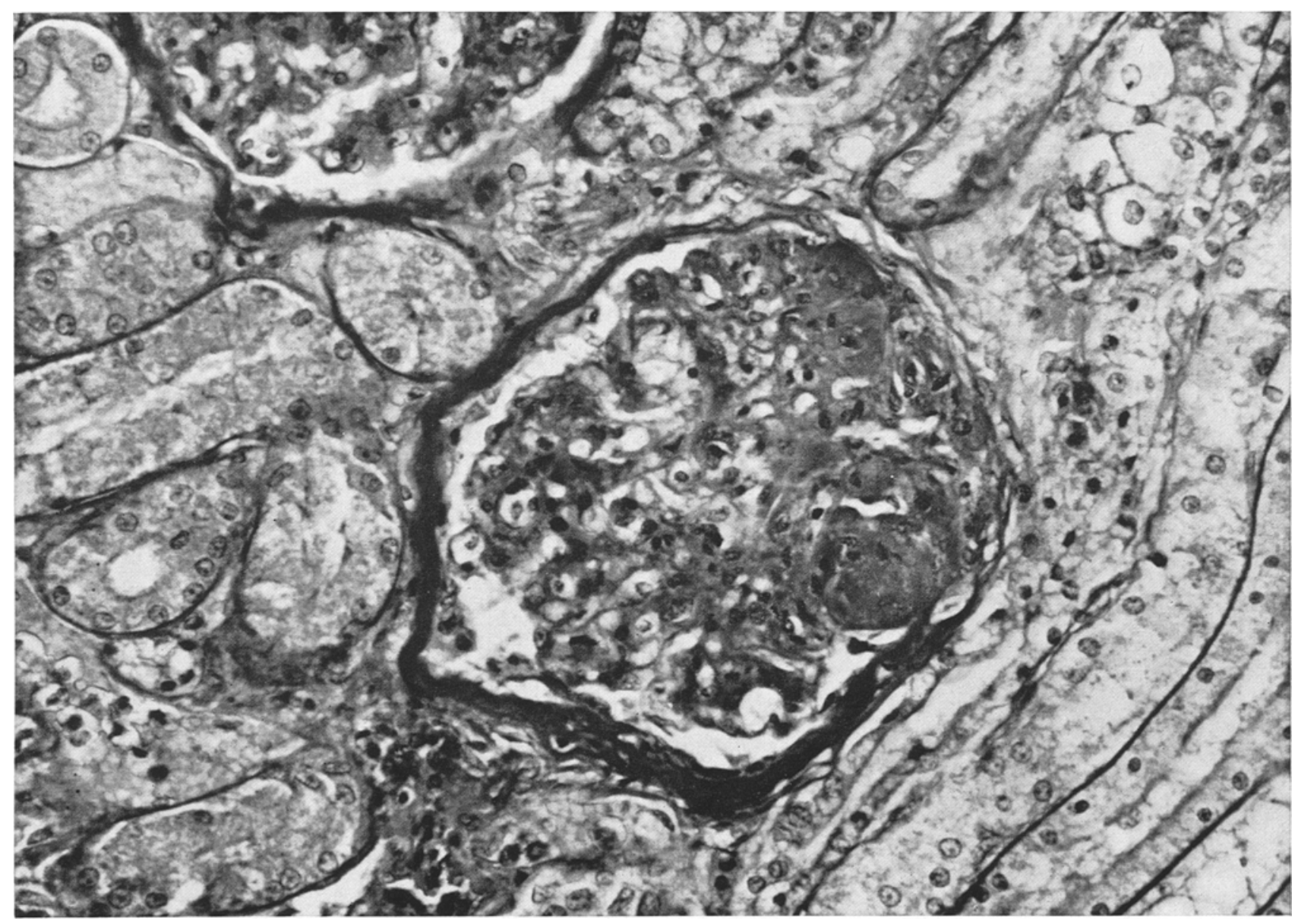

Fig. 9. Diabetic Dog (No. 59). Kidney. Diffuse thickening of the basement membranes, with tendeney to formation of nodules. $400 x$

pituitaries. The cytological study of these pituitaries is not yet completed and will be reported in a later publication.

\section{Discussion}

General discussion. The fairly large number of dogs that we have been able to collect with the assistance of only a small number of veterinarians, confirms Meier's statement that, at least in dogs, spontaneous diabetes is not a rare disease. Many more cases could have been studied, were it not for the refusal of many owners to donate their dog, even after euthanasia had been performed. The same psychological factor is mainly responsible for the regrettable lack of physiological and biochemical data on these diabetic dogs. Although a purely morphological study provides only a onesided and not necessarily correct picture of the disease, in the case of our dogs and cats it has revealed a number of facts that throw some light on the nature of the diabetes in these animals.

Concerning age, our data are similar to those from the literature: in dogs and cats, diabetes tends to appear in elderly animals. A predisposition for the female sex has also been mentioned in all previous studies on spontaneous canine diabetes. On the other hand, a review of the literature reveals, that in cats diabetes is more frequent in males than in females. This fact is not born out by our personal data, since in our materiai, 3 cats were females and 2 males. However, the relatively small number of cats at our disposition does not permit a valid conclusion on this point.

Nothing is known about the genetic aspect of canine or feline diabetes. In this respect the occurence of a diabetes in the mother and a female litter-mate of one of our diabetic dogs is worth pointing out. Teunissen and Blok-Schuring [36] have reported a diabetes occuring in a female whippet and in 2 females of her litter of 4 females and 1 male. Although a few authors $[2,38]$ have suggested that diabetes might be more frequent among smaller breeds of dogs, no such racial predisposition emerges from our material. Neither has it been observed in other studies on a large number of dogs $[9,36]$.

Obesity has been mentioned repeatedly in studies on spontaneous diabetic dogs, but was only rarely present in our material. According to one of our contributing veterinarians, it is more frequent in diabetic cats than in dogs. This could be of interest in view of 


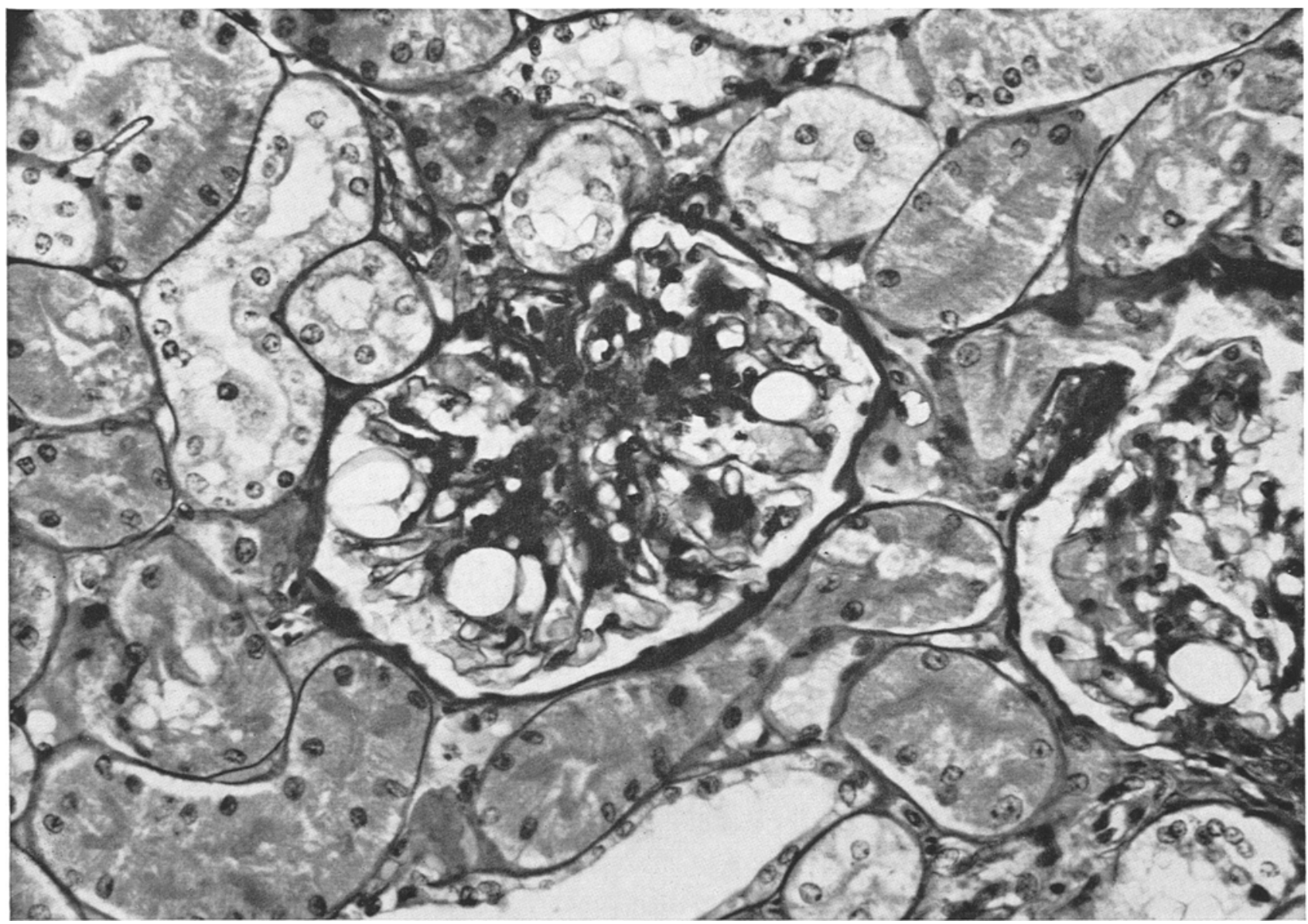

Fig. 10. Diabetic Dog (No. 73). Kidney. Thickening of the mesangial stalk. A few capillaries are distended (by fat?). $400 \times$

the marked differences that we found in our material in the aspect of the islet tissue between diabetic dogs and cats.

Pancreatic lesions. It has been claimed by several authors $[26,35,4,40,41,17,9]$, that in dogs, diabetes is often the consequence of a widespread destruction of the pancreas by acute or chronic inflammatory lesions. For this reason, a distinction has been made in dogs between secondary diabetes, due to pancreatitis, and a true idiopathic type with primary lesions in the islet tissue. Although the descriptions that can be found in literature leave no doubt that the first type does occur, we feel that its frequency has perhaps been overestimated by some authors. In our study, the pancreas appeared grossly normal in most of the animals. Although we did find inflammatory lesions in the pancreas of some of the diabetic dogs and cats, we feel that they could not explain the severe changes that were present in the islet tissue. Some of the acute lesions could well represent a terminal complication that had developed during the final stage of diabetic metabolic decompensation.

The changes that we have reported in the islettissue of the diabetic dogs are in many respects similar to those that have been described in earlier studies on spontaneous canine diabetes $[26,14,35,32,4,42,8$, $40,41,5,17,11,28,36,9]$. Reduction in the number and size of the islets, and hydropic B cells, thus appear to be characteristic features of spontaneous diabetes in dogs. In cases of longer duration, the $B$ cells have completely disappeared, leaving behind either small islets composed of atrophic cells, or no islets at all. This sequense of events resembles what occurs in the pancreas of human juvenile diabetics [10]; a similarity which has already been pointed out by WRENSHALL et al. [42]. In both human diabetics and diabetic dogs, B cells are still present when the disease breaks out clinically. The cytological characteristics of these cells, clearly point to a marked secretory hyperactivity. However, the progressive destruction of the B cell proceeds rapidly and reaches its full completion only a short time after the clinical onset of the disease. Irrespective of what the primary cause may be, it appears that in human juvenile patients and in dogs, at the moment that diabetes appears clinically, it has already reached the pancreatoprive stage of the disease.

From what we have observed in our material, the situation might well be different in cats. In all 5 cats 


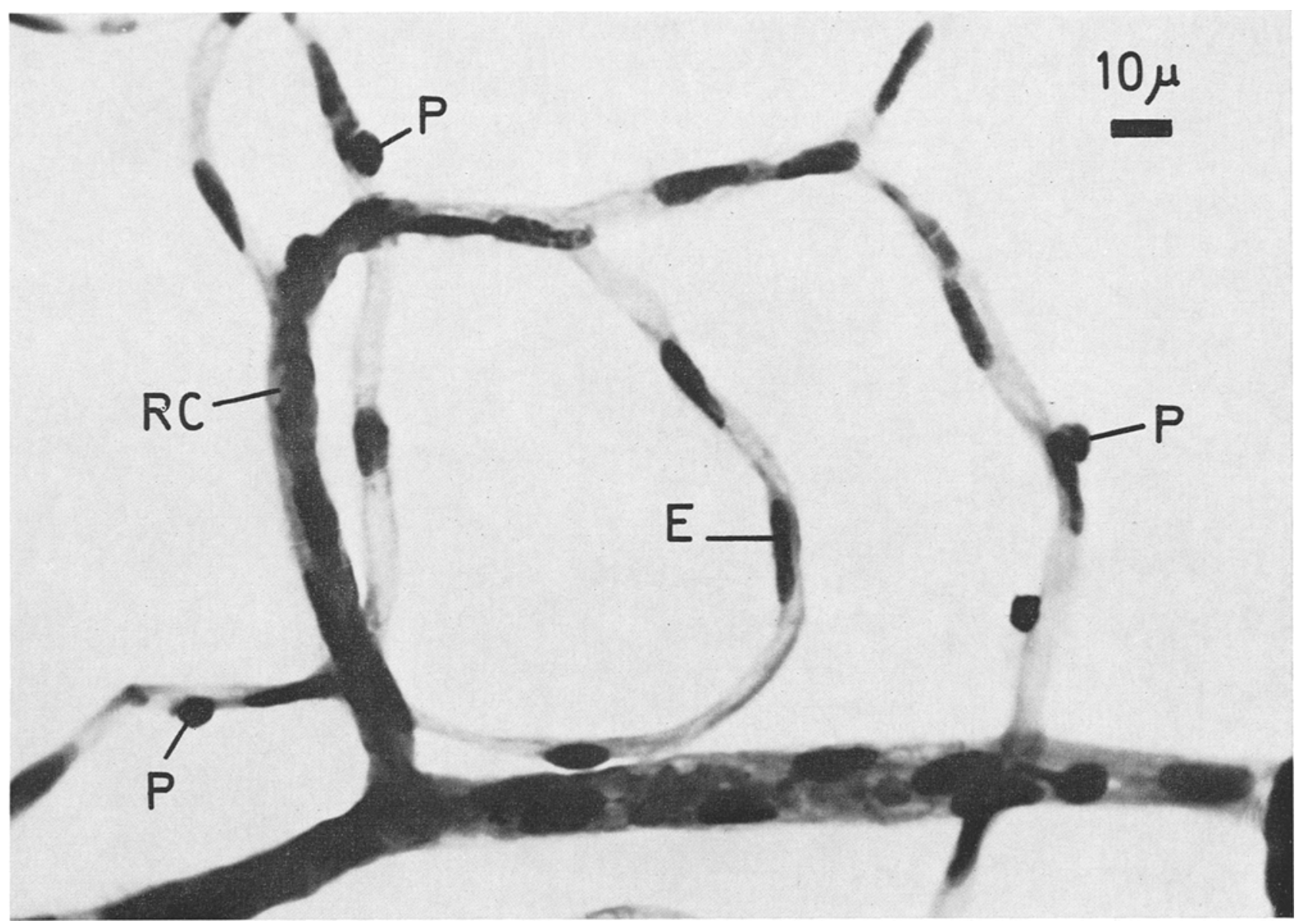

Fig. 11. Normal Dog. Retinal vessels. Trypsinic digestion. Pericytes (P). Endothelial cells (E). Red blood cells (RC). PAS-Toluidine blue

that we have been able to study, the islets and the $\mathrm{B}$ cells were still numerous. It is true that in all but one case the $B$ cells appeared markedly vacuolated. However, LAzarus and VoLK [20] have demonstrated that this type of change does not necessarily represent a degenerative lesion. Only in cells with an extreme degree of swelling and vacuolisation ("ballooning degeneration"), with nuclear pycnosis, did they find ultramicroscopical evidence of damage to the cell organelles. A distinction between hydropic change due to glycogen deposition only, and true ballooning degeneration is not always easy to make with the light microscope.

None of the authors that previously reported on the islet tissue in spontaneously diabetic eats, seem to have been impressed, as we were by the large number of islets and B cells present. It may be that their cases were studied in a later stage of the disease. Nevertheless, in our material a striking difference exists in regard to the islet tissue between dogs and cats with an equivalent duration of diabetes. This could well represent an expression of a stronger resilience of the cat pancreas against an extra-pancreatic diabetogenic factor. It is possible that the pancreas of the cat might be able to fulfill better than that of the dog the increased requirements of insulin by producing new islets and new B cells for a longer time. The interest of a comparative physiological and biochemical study of diabetes in these two species appears clearly from our findings.

Hyalin deposits in the islet stroma have been reported repeatedly in spontaneously diabetic cats $[26,35,39,34,33]$. They have also been found in experimental diabetes produced by growth-hormone. As far as we know they have never been described in spontaneously diabetic dogs. In man, they are rare in juvenile diabetics but are present in about $45 \%$ of maturity-onset diabetics. The pathogenesis of islet hyalinosis has not yet been elucidated. There is an almost general agreement that the hyalin substance has the same staining characteristios as amyloid; however, amyloid has not been found in organs other than the pancreas. In the human, the same hyalin substance occurs in some islet tumors, but only in those that secrete insulin. This fact suggests that the hyalin deposits could be related to a prolonged local hypersecretion of insulin, damaging the stroma of the islet tissue. That it never occurs in spontaneously diabetic 


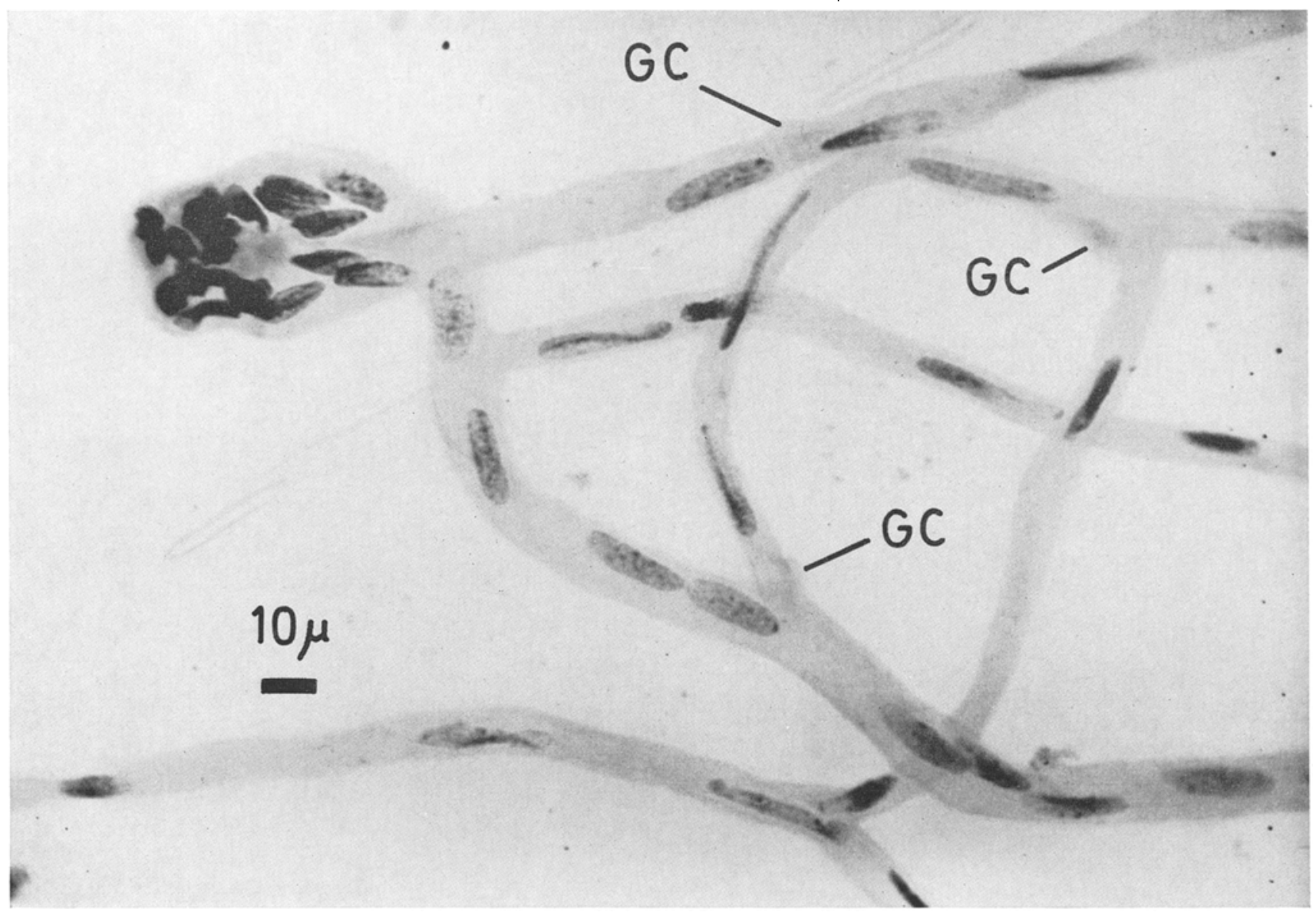

Fig. 12. Diabetic Dog (No. 83). Retinal vessels. Trypsinic digestion. Ghost cells (GC). PAS-Toluidine blue

dogs and only rarely in human juvenile diabetics, may be explained by the fact that in these forms of diabetes the survival of the B cells, in the newly formed islets, is too short for the deposits to develop.

Another finding of considerable importance is a dense inflammatory infiltrate in an islet in one diabetic cat. To the best of our knowledge, this is the first time that such a lesion has been reported in cats. Inflammatory infiltrates in and around the islets are present in about $60 \%$ of human juvenile diabetics dying less than 1 year after the clinical onset of the disease [10]. They have also been described in a case of spontaneous diabetes in a cow [3]. Although the significance of our finding in a diabetic cat is diminished by the fact that we were able to detect it in only one islet and in one animal, it cannot be ignored in view of the striking similarity between this lesion and those that have been seen in human juvenile diabetics and reproduced experimentally in cows, sheep and rabbits. The possible etiology and significance of inflammatory lesions in the islet tissue have been thoroughly discussed in a recent paper by LeCoMPTE et al. [21]. The two most appealing hypotheses are: 1. an infectious etiology, 2. an auto-immune reaction. The first hypothesis is supported by the occurence of cases of diabetes after viral infectious diseases, such as mumps. The autoimmune hypothesis has received considerable support from recent experimental work [21, 30, 12]. Several groups of authors have succeeded in reproducing these lesions experimentally with procedures involving an immuno-pathological reaction. LeCompte et al. [21] point out that these two theories are not necessarily exclusive, since it appears that many post-infectious complications of viral infections involve a late autoimmune reaction.

From earlier publications, and from our own observations, it is evident that striking abnormalities are present in the islet tissue in almost every spontaneously diabetic dog or cat. In our material, 3 cases appear to be exceptions to this rule. In 2 dogs $(35,68)$ and in 1 cat (62), the islets appeared almost normal, except for some degranulation in the 2 dogs. We have no straightforward explanation of these cases. One possibility is that they were not really diabetic. Whereas this explanation could eventually hold for cat 62 , it appears unlikely for the 2 dogs. In dog 35, 2 glycemias had been performed $(3.36 \mathrm{~g} / \mathrm{l}$ and $4.4 \mathrm{I} \mathrm{g} / \mathrm{l})$. In $\operatorname{dog} 68$ only one glycemia $(2.30 \mathrm{~g} / \mathrm{l})$ was performed, but glycogen was present in the ascending limb of the loops of Henle, a finding almost specific for diabetes. Another 


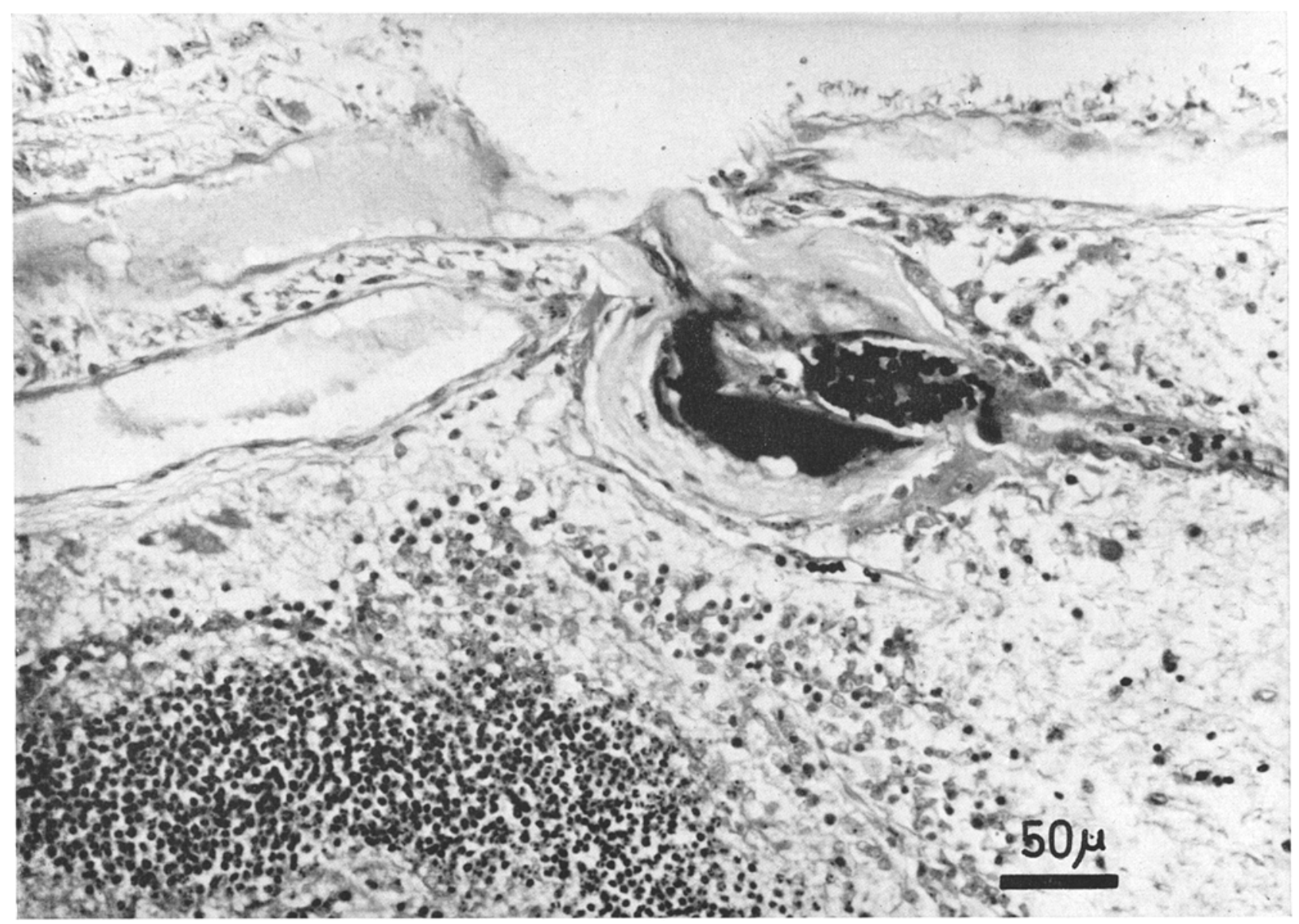

Fig. 13. Diabetic Dog (No. 28). Flat mounted retina embedded in paraffin. Microaneurysm in the ganglion cell layer. Masson trichromic stain

possible explanation could be that, as in the human, two types of diabetes exist in dogs and cats. In maturity-onset human diabetes, it oceurs fairly often, that, in spite of a persisting hyperglycemia and the absence of insulin treatment, the individual islets look qualitatively normal, with well granulated B cells. It has been suggested that in these cases the $B$ cells do not react normally to the stimulus of hyperglycemia. This secretory inertia of $B$ cells in human maturity onset diabetics, has been confirmed by biological observations $[29,43]$. Contrary to what exists in man, the severe and rapidly progressing type of the disease would be the prevailing type in dogs, and would present itself at a later age in life. However, as far as we know, no survey of the incidence of diabetes in a large population of living dogs hás been performed up to now. It may well be, that only the more severe cases have come to our attention, while many more benign cases go on unnoticed.

Kidneys. No exact counterpart of human diabetic glomerulosclerosis, either of the diffuse or the nodular type has been found in our dogs or cats. In earlier studies on spontaneous canine or feline diabetes, glomerular changes simulating the human lesions have been reported [32, 42, 28, 27]. PAтz et al. [27, 28] examined kidneys from diabetic dogs and controls, by light and electron microscopy. They found a significantly greater incidence and severity of diffuse glomerulosclerosis and thickening of the basement membrane in diabetic dogs than in the controls.

Focal, occasionally generalized, thickening of the glomerular intercapillary stroma, and of the capillary wall proper, was also observed in long-term experimental diabetes in dog $[22,31]$. That the lesions, which have been described in spontaneously or experimentally diabetic dogs, are identical to those in the glomeruli of human diabetics is difficult to prove. It could well be that these lesions merely represent an accentuation of the aging changes encountered in the kidneys of non-diabetic dogs.

Hyalinosis of the afferent and efferent arterioles, a characteristic feature in the kidney of many human diabetics, has not been observed in our dogs or cats. Thickening of the wall of the afferent arteriole was well pronounced in many of our cases, and this finding has also been reported by Dixon and SANFord [5]. These authors point out that this lesion is not pathognomonic of diabetes mellitus since it is also present 


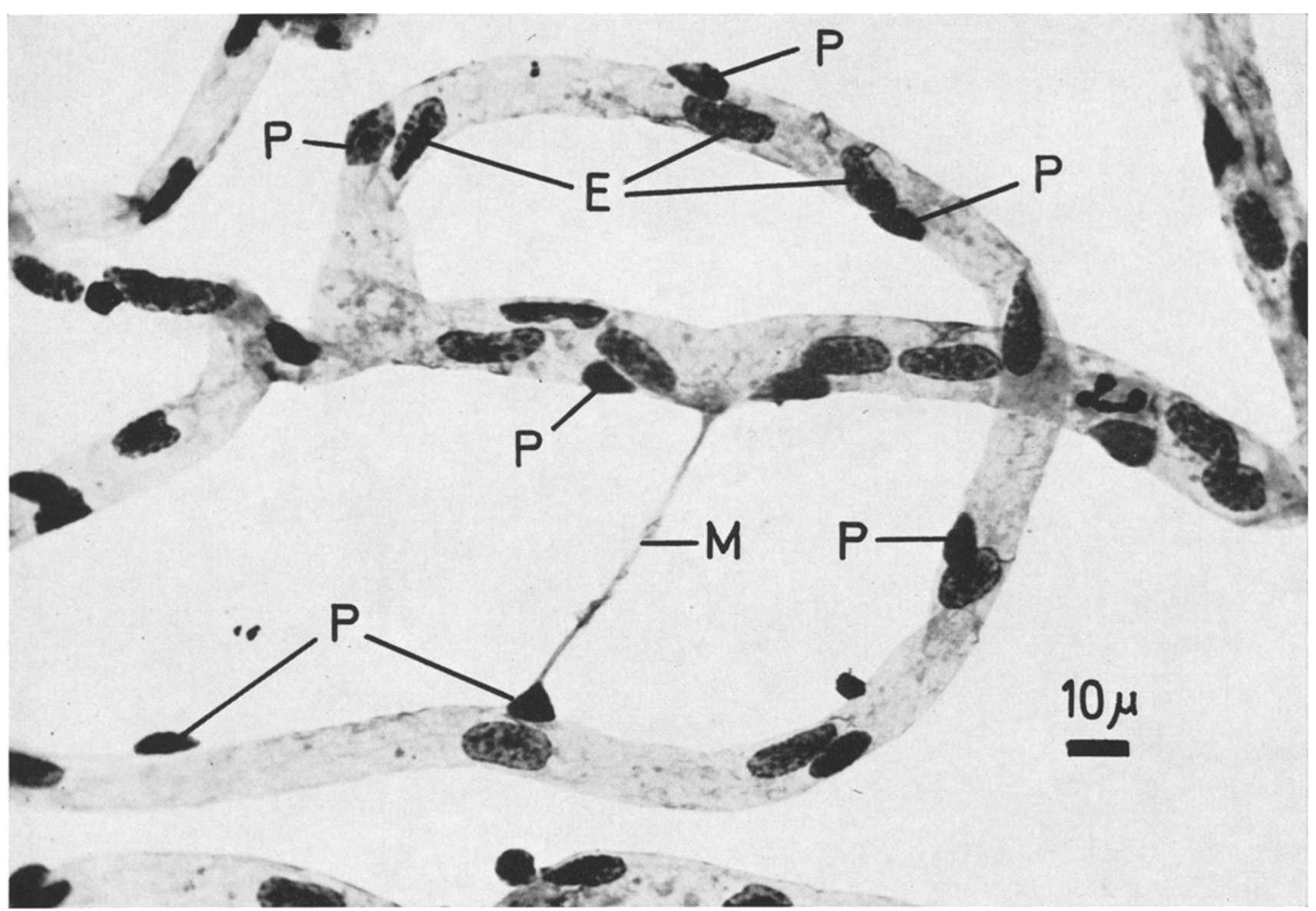

Fig. 14. Normal Cat. Retinal vessels. Trypsinic digestion. Pericytes (P). Endothelial cells (E) Mesodermic tract (M). PAS-Toluidine blue

in many non-diabetic aged dogs and in dogs made hypertensive experimentally for periods of several years.

Although the duration of the diabetes exceeded one year only in a few of our dogs and in none of our cats, we feel inclined to believe that in these species the lesions in the kidney are much less pronounced and characteristic than in human diabetics.

Retinal vascular changes. The same impression has been gained from the study of the retinal vessels in our diabetic dogs and cats. A number of changes, such as focal or diffuse loss of endothelial cells and pericytes, mural ghost cells, are undoubtedly much more frequent in diabetic dogs than in non-diabetio controls. However, microaneurysms have been found in small numbers and in 3 dogs only. Convincing examples of diabetic retinopathy have been described by Patz et al. [27, 9] in 2 dogs, with a respective duration of diabetes of 1 year and $2^{1 / 2}$ years. HAUSLER [13] described microaneurysms and hemorrhages in a metasomatotrophin-diabetic dog, that had remained in the diabetic state for a period of ten years; there were reasons to believe that the retinal lesions had developed during the final two years. ENGERMAN and BLOODWORTH [6] described typical lesions of diabetic retinopathy, in an alloxan-diabetic dog and in two dogs with growth hormone diabetes. RIOKETTS et al. $[32,31]$ failed to detect retinal changes in dogs with long standing spontaneous or experimental diabetes. However, this failure may at least partly be due to the fact that the retinas were examined with the whole mount technique, before the development of the trypsin digestion method.

The paucity of mieroaneurysms and other changes typical of diabetic retinopathy, may well be related. to the relatively short duration of the diabetes in many of our dogs and eats. This would suggest that the duration required for the diabetic condition to produce retinal vascular complications, must be calculated in an absolute number of years, and not relatively to the duration of life. However, it cannot be excluded that the retinal capillaries of dogs and cats are less susceptible to develop degenerative changes than in the human. In a large group of nondiabetic patients, who for some reason or other had been submitted to a prolonged cortisone treatment, ToussatnT and Fardir [37] observed large numbers of micro-aneurysms in those patients that had developed hyperglycemia. On the other hand, no retinal changes whatsoever were found in dogs and cats, rendered 


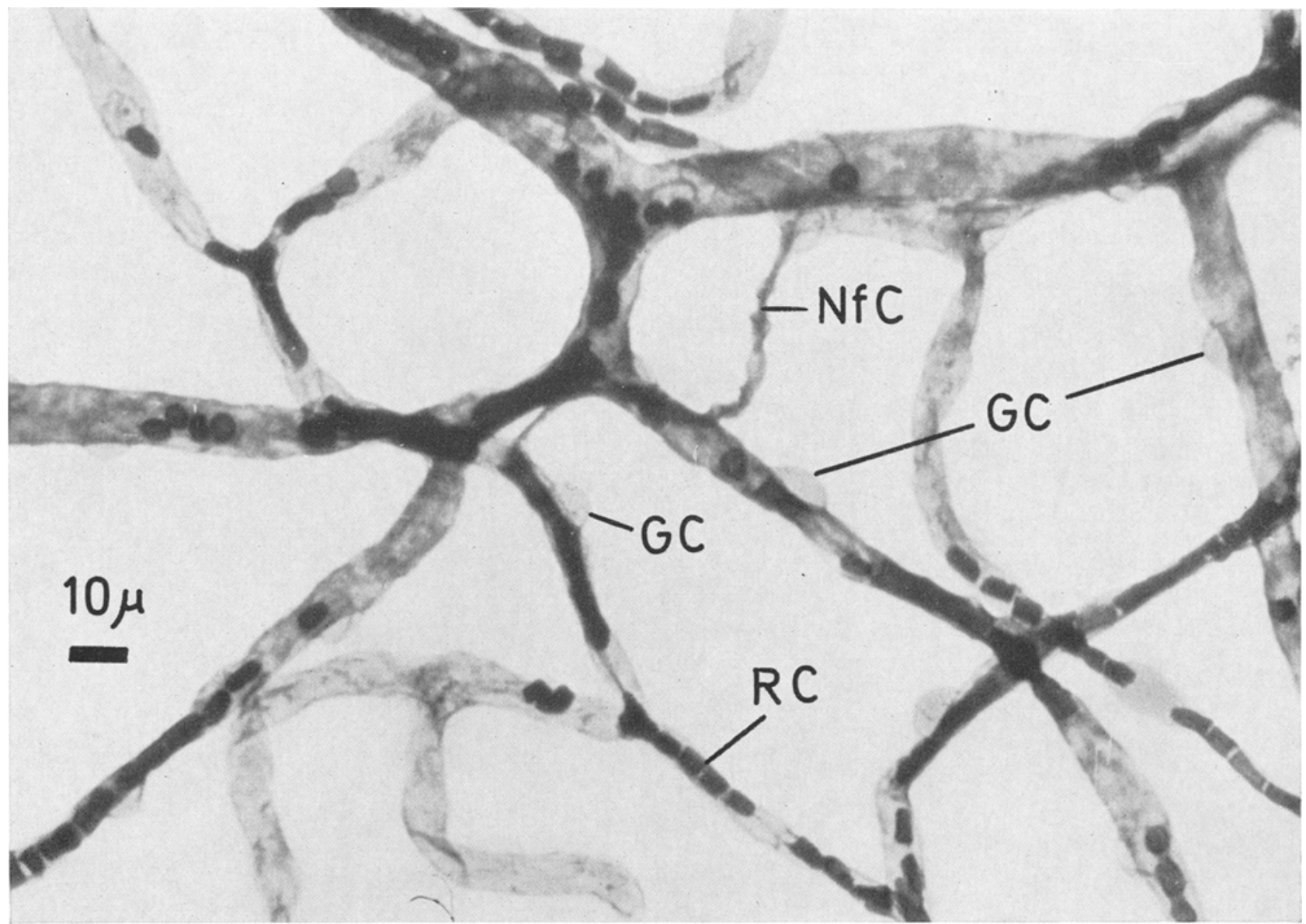

Fig. 15. Diabetic Cat (36). Retinal vessels. Trypsinic digestion. Ghost cells (GC). Non-functional capillary (NfC). Red blood cells (RC). Red blood cells (RC) PAS-Toluidine blue

hyperglycemic by a prolonged administration of cortisone.

Liver. Fatty change was present in the liver of many dogs and cats. In 4 dogs the liver also showed incipient cirrhosis. Similar changes have been mentioned in earlier reports on diabetic dogs and cats. The pathogenesis of these lesions cannot be deduced from their histological aspect. Numerous metabolic disturbances can lead to accumulation of fat in the liver cells. Severe steatosis develops in the liver of pancreatectomised dogs maintained with insulin $[1,7]$.

Adrenals. The high incidence of cortical hyperplasia and adenomas seems impressive at first sight. However similar changes have been reported, with the same frequency, in non-diabetic aging dogs [17, 9].

Pituitary. The changes in the pituitary of diabetic dogs will be discussed when the results of the cytological study, now under progress, are reported. The presence of an adenoma in 2 of the 7 pituitaries that were available is worth pointing out, since the literature contains at least 2 other cases of spontaneous animal diabetes existing together with a pituitary tumor [19].
Acknowledgement. The authors are very grateful to the veterinarians who contributed diabetic dogs and cats: Dr. R. Dufatt (Antwerp), Dr. A. Guichaux and Dr. Lomba (Brussels). - The skilful technical assistance of Mr. A. Demeire, Mrs A. Denetire-Medaer, Mrs.. M. L. Poeckens and Miss D. DeRycke is also acknowledged.

\section{References}

[1] Allan, F.N., D.J. Bowte, J.J.R. McLwod and W.L. RoBINSON: Behaviour of depancreatized dogs kept alive with insuline. Brit. J. exp. Path. 5, 75-83 (1924).

[2] ApEL, S.: Klinische Erfahrungen beim Diabetes Mellitus des Floischfressers. Berl. Münch. tierärztl. Wschr. 72, 295 (1959) (quoted from GärTNER, K.).

[3] Christensen, N.O., and P. Schambrye: On diabetes mellitus hos kvaeg. Nord. Vet.-Med. 2, 863-900 (1950).

[4] Cofftr, D.L., and A. Thordad-Christensen: The clinical and some pathological aspects of pancreatic disease in dogs. Vet. Med. 48, 193-196 (1953).

[5] DIXON, J.B., and J. SANFORD : Pathological features of spontaneous canine diabetes. J. comp. Path. 72, $153-164$ (1.962).

[6] Engerman, R.L., and J.M. B. Bloodworth: Experimental diabetic retinopathy in dogs. Arch. Ophthal. 73, 205-210 (1965). 
[7] Fisher, N.J.: Attemps to maintain the life of totally pancreatectomized dogs indefinitely by insulin. Amer. J. Physiol. 67, 634-643 (1923-24).

[8] Frevdiger, U., und H. KöHLER: Klinische und pathologisch-histologische Untersuchungen bei einem Fall von Diabetes mellitus des Hundes. Schweiz. Arch. Tierheilk. 97, 188-198 (1955).

[9] GäRTneR, K.: Der spontane Diabetes mellitus bei Haustieren. To appear in: "Handbook of Diabetes Mellitus".

[10] GEPTs, W.: Pathological anatomy of the pancreas in juvenile diabetes mellitus. Diabetes 14, $619-633$ (1965).

[11] Grokn, J.J., H.S. FrenkmL and L. OfFerhats: Observation on a case of spontaneous diabetes mellitus in a dog. Diabetes 13, 492-499 (1964).

[12] Grodsky, G.M., R. Fecdman, W.E. Touson and J.C. LEE: Diabetes mellitus in rabbits immunized with insulin. Diabetes 15, 579-585 (1966).

[13] Hausler, H.R., T.M. Sibay and J. Campbell: Retinopathy in a dog following diabetes induced by growth-hormone. Diabetes 13, 122-126 (1964).

[14] HJÄRRE, A.: Sektionsbefund beim Diabetes Mellitus des Hundes und der Katze. Arch. wiss. prakt. Tierheillk. 57, 1-76 (1928).

[15] Holzworth, J., and D.L. Cofres: Pancreatic insufficiency and diabetes mellitus in a cat. Cornell Vet. 43, 502-512 (1953).

[16] Ivı,, M.: Neue selektive Farbmethode der A- und B-Zellen der Langerhans'schen Inseln. Anat. Anz. $107,347-350(1959)$.

[17] KAST, A.: Pathologisch-anatomische Grundlagen des spontanen Diabetes Mellitus bei den Haustieren. Berl. Münch. tierärztl. Wschr. 13, 252-255 (1962).

[18] Kreer, J.M.: Diabetes mellitus in a Persian Cat. Aust. vet. J. 30, 347 (1954).

[19] KING, J.M., J.F. Kavanotgh and J. BentinckSмrтH: Diabetes mellitus with pituitary neoplasms in a horse and a dog. Cornell Vet. 52, 133-145 (1962).

[20] LAZARUS, S.S., and B. VoLK: The pancreas in human and experimental diabetes. p. 261-262. New York: Grune \& Stratton 1962.

[21] LmCoMpte, Ph.M., J. Steinke, J.ST. SOELDNER and A.E. RENowd: Changes in the islets of Langerhans in cows injected with heterologous and homologous insulin. Diabetes 15, 586-596 (1966).

[22] Lukens, F.D.W., and F.C. Dohax: Experimental pituitary diabetes of five years' duration with glomerulosclerosis. Arch. Path. 41, 19-24 (1946).

[23] Mavocchio, F.: Metachromasia e basofilia delle cellule insulare alfa nel pancreas di mammiferi dopo metilazione e demetilazione. Arch. vet. ital. 15, 3-7 (1964).

[24] Masson, P.: Tumeurs humaines. Paris : Maloine 1956.

[25] McEvor, J.P.: Diabetes in the cat. N. Amer. Vet. $30,449-461(1949)$

[26] Meter, H.: Diabetes mellitus in animals. Diabetes 9, $485-489(1960)$.

[27] Patz, A., and A.E. Maumenee: Studies in diabetic retinopathy - I. Retinopathy in a dog with sponta- neous diabetes mellitus. Amer. J. Ophthal. 54, 532$541(1962)$.

[28] - J.W. Berkow, A.E. Maumenee and J. Cox: Studies on diabetic retinopathy. II. Retinopathy and nephropathy in spontaneous canine diabetes. Diabetes 14, 700-708 (1965).

[29] Patiffer, E.F., H. Ditschuneit and R. Ziegler: Über die Bestimmung von Insulin im Blute am epididymalen Fettanhang der Ratte mit Hilfe mar. kierter Glucose. Klin. Wschr. 39, 415-426 (1961).

[30] Reroxd, A.E., J.S. Sotloner and J. Steinke : Immunological studies with homologous and hetero. logous pancreatic insulin in the cow. In Ciba Foundation Colloquium, Vol. 15. Etiology of Diabetes mellitus and its complications. p. 122. Boston: Little Brown and Co. 1964.

[31] Ricketes, H.T., C.E. Test, E.S. Petersen, H. Lints, N. Tupikova and P.E. Steiner: Degenerative lesions in dogs with experimental diabetes. Diabetes 8, 288-294 (1959).

[32] - E.S. Peterson, P.E. Steiner and N. Tupikova: Spontaneous diabetes mellitus in the dog. An account of eight cases. Diabetes 2, 288-293 (1953).

[33] Rubarth, S.: Diabetes mellitus in a cat. $\mathbf{N}$. Amer. Vet. 17, $49(1936)$.

[34] - The degeneration of amyloid in the Langerhans cell islands as the cause of diabetes mellitus in the cat. Scand. Vet. Tidskrift 25, 750-761 (1935).

[35] Schlotrhautr, C.F., and J.A.S. MmLar: Diabetes mellitus in dogs and cats. J. Amer. vet. 118, 31-35 (1951).

[36] Trunissen, G., and P. Blok-SchuRdrg: Diabetes mellitus bei Hund und Katze. Schweiz. Arch. Tierheilk. $108409-427(\mathbb{1 9 6 6 )}$.

[37] Toussaint, D., and A. Farnir: Etude de la vascularisation rétinienne de sujets traités à la cortisone. Bull. Soc. belge Ophtal. To be published.

[38] WaldrafF, H.P.: Der Diabetes mellitus in der tierärztlichen Literatur. Diss. Giessen (1961) (quoted from GäRTNER, K.).

[39] Warren, SH., PH.M. Lecompte and LegG: Spontaneous diabetes in animals. In "Pathology of diabetes mellitus"'. Philadelphia, Lea \& Febiger, 1966.

[40] Wilkenson, J.S.: Spontaneous diabetes mellitus in domestic animals. Vet. Rev. Annot. 3, 69-96 (1957).

[41] - Spontaneous diabetes mellitus in domestic animals. Vet. Rev. Annot. 4, 93-117 (1958).

[42] Wrenshat, G.A., W. St. HARtroft and C.H.Best: Insulin extractable from the pancreas and islet cell cytology. Diabetes 3, 444-452 (1954).

[43] ÝLOW, R.S., and S.A. BERSON: Immuno assay of plasma insulin in man. Diabetes 10, 339-344 (1961).

Docteur WrLIt Gepts

Laboratoire d'Anatomie Pathologique

Université Libre de Bruxelles

Hôpital Brugmann

4, Place Van Gehuchten

Bruxelles 2, Belgique 